\title{
Evidentiality and interrogativity
}

\author{
Lila San Roque ${ }^{a, b, *}$, Simeon Floyd ${ }^{a}$, Elisabeth Norcliffe ${ }^{a}$ \\ a Language and Cognition Department, Max Planck Institute for Psycholinguistics, PO Box 310, \\ 6500 AH Nijmegen, The Netherlands \\ ${ }^{\mathrm{b}}$ Centre for Language Studies, Radboud University, PO Box 9103, 6500 HD, Nijmegen, The Netherlands
}

Received 29 May 2013; received in revised form 21 August 2014; accepted 12 November 2014

Available online 31 January 2015

\begin{abstract}
Understanding of evidentials is incomplete without consideration of their behaviour in interrogative contexts. We discuss key formal, semantic, and pragmatic features of cross-linguistic variation concerning the use of evidential markers in interrogative clauses. Crosslinguistic data suggest that an exclusively speaker-centric view of evidentiality is not sufficient to explain the semantics of information source marking, as in many languages it is typical for evidentials in questions to represent addressee perspective. Comparison of evidentiality and the related phenomenon of egophoricity emphasises how knowledge-based linguistic systems reflect attention to the way knowledge is distributed among participants in the speech situation.
\end{abstract}

(C) 2014 Elsevier B.V. All rights reserved.

Keywords: Conjunct/disjunct; Egophoricity; Epistemics; Evidentiality; Interrogativity; Perspective

\section{Introduction}

Interrogative utterances that are marked for evidentiality bring together two facets of the expression of epistemicity in language. Evidential morphology is usually understood as encoding the expression of knowledge, in particular, the source of information one has for a proposition (e.g., Anderson, 1986; Aikhenvald, 2004; Willet, 1988). Interrogative marking is typically associated with the speech act of questioning (Chisholm, 1984; Sadock and Zwicky, 1985), a central function of which is to request information that is not known to the speaker. ${ }^{1}$ Evidential marking in interrogatives thus seems in some ways paradoxical, as the things we ask about are likely to be those things that we know little about. Indeed, evidentially marked interrogatives are reported to be infrequent in various languages (e.g., Maslova, 2003), and in some languages evidentials apparently cannot be used in interrogatives at all (e.g., Aikhenvald, 2004a). Yet many languages with evidentials do allow their occurrence in interrogatives. While little attention was paid to this distributional fact in early literature on evidentiality, our understanding of evidentials is incomplete without considering their behaviour in interrogative contexts, especially given that evidential markers can mean different things in questions than in statements (see, e.g., Aikhenvald, 2004a; Davis et al., 2007; Faller, 2002a; Garrett, 2001; de Schepper and de Hoop, 2012). We must be able to account for such differences and explain how evidential semantics are operationalised in the give-and-take of conversational interaction, the primary site of language use and change (Enfield and Levinson, 2006; Nuckolls and Michael, 2012). Evidential use in interrogatives is also essential to the issue of whether evidentials are considered deictic

\footnotetext{
* Corresponding author.

E-mail addresses: I.sanroque@let.ru.nl (L. San Roque), simeon.floyd@mpi.nl (S. Floyd), elisabeth.norcliffe@mpi.nl (E. Norcliffe).

${ }^{1}$ Although they may also accomplish many other things besides, see, e.g., de Ruiter (2012), Harris (1984), Levinson (1983), Searle (1969), Stivers et al. (2010).
} 
(e.g., as explicitly argued by De Haan, 2005 and discussed by Hanks, 2012) and thus, perhaps, to our understanding of referential indexicals or 'shifter' categories (Jespersen, 1924; Jakobson, 1957) more generally.

In this paper, we develop a partial typology of evidentials in interrogative sentences (or 'interrogative evidentials' for short), building on earlier typological work (see especially Aikhenvald, 2004a:242-249) and charting cross-linguistic variation with respect to certain formal, semantic and pragmatic properties. Our data are drawn from field notes on Quechua (as spoken in Ecuador), Duna (Papua New Guinea) and two Barbacoan languages (Ecuador/Colombia), augmented with other sources concerning further relevant languages. Because, at least historically, there has been little systematic documentation of interrogative evidentials (one exception being the studies in Aikhenvald and Dixon, 2003), our survey is necessarily restricted in scope. A secondary objective of this paper is therefore to signpost areas in need of further documentation and analysis.

Example (1) is a (constructed) Duna question-answer pair that illustrates an evidentially marked interrogative clause. The question is formally marked as interrogative with the particle $=p e$ and includes the evidential -yarua which indicates non-visual sensory information source (in this case, the sensation of internal temperature). The same morpheme is used in the (declarative) response. ${ }^{2}$

$\begin{array}{ll}\text { A: } & \text { ko roro-yarua=pe } \\ & \text { 2sG hot-SENS=INTER } \\ & \text { 'Are you hot (you feel)?' } \\ \text { B: } \quad \text { no roro-yarua } & \text { 1sg hot-SENS } \\ & \text { I am hot (I feel).' }\end{array}$

Examples such as (1) illustrate the importance of understanding evidentials as linguistic markers that not only supply information about information, but also relate that information to the participants in the speech situation. This is made possible (or inevitable) because of their 'perspectivising' quality. Evidentials encode perceptual or cognitive experience, presenting a situation "with reference to its perception by a conscious subject" (Johanson, 2000:61). The conceptual role of this conscious subject-the person who sees, hears, infers, and so on-has been labeled various ways in the literature, for example 'observer' (Aikhenvald, 2004a), 'experiencer' (Mushin, 2001), and 'evidential origo' (Brugman and Macaulay, 2010; Garrett, 2001). Speas (2004) goes so far as to argue that the 'witness' role projected by evidentials is in fact an implicit argument that can have syntactic reality in the clause (see also Speas and Tenny, 2003; Tenny, 2006). ${ }^{3}$ But who is this witness? And is their identity specified as part of the meaning of the evidential (indexically or otherwise), or determined on an ad hoc basis?

The perceptual anchor of an information source marker in an independent clause is often co-identified with the speaker, so that the person talking chooses an evidential appropriate to his or her (espoused) perspective on the situation. For example, in (1), above, we understand that speaker B, in answering the question, uses the non-visual sensory evidential -yarua with reference to his or her own perceptual experience. The feature of 'speaker's evidence' has even been incorporated into definitions of evidentiality; Brugman and Macaulay (2010) found that 27 out of 38 sample definitions in the literature explicitly characterised the speaker as evidential origo. This is in keeping with a general expectation that subjectivity in language is concerned with speaker beliefs and attitudes (e.g., Lyons, 1982) and, more broadly, a possible cognitive bias toward egocentric perspective (e.g., Barr and Keysar, 2007; Rubio-Fernández, 2008). Some scholars have further argued that, through the association between speaker and evidential origo, evidentiality is in fact a deictic category that "fulfills the same function for marking relationships between speakers and actions/events that, say, demonstratives do for marking relationships within speakers and objects" (De Haan, 2005; see also Schlichter, 1986:56-58).

While speaker perspective may be the most prototypical in evidential usage, many studies of individual languages have indicated that an exclusively speaker-centric view of evidential perspective greatly oversimplifies the situation. For

\footnotetext{
${ }^{2}$ Abbreviations in interlinear glosses follow those suggested in the Leipzig Glossing Rules (http://www.eva.mpg.de/lingua/resources/glossingrules.php) with the following additions: AG,agent; ASSERT, assertion; ATTR, attributive; DEP, dependent; DIR, directional prefix; DISC, discontinuative; EGO, egophoric; EV, best evidence; EXIS, existential; FP, far past; HS, hearsay; II,intransitive inanimate; INDB, indubitative; INF, inferential; INTER, interrogative marker; N.EGO, non-egophoric; PLN, place name; PROX, proximal; PSN, personal name; REAS, reasoning; REP, reportative; sENS, non-visual sensory; SPEC, specific; TI, transitive inanimate; UNC, uncertainty; vIS, visual; $\mathrm{Y} / \mathrm{N}, \mathrm{yes} / \mathrm{no}$ question. Duna language examples are from San Roque's field notes and corpus (see also San Roque, 2008; San Roque and Loughnane, 2012). Ecuadorian Quechua and Cha'palaa examples are from Floyd's field notes and corpora (see also Floyd, 2005, 2010, 2011 for more general information on Cha'palaa and Ecuadorian Quechua), and Guambiano examples are from Norcliffe's field notes and corpus.

${ }^{3}$ In Jakobson (1957) terms and with respect to reported evidentiality, this role can be defined as a participant (the hearer) in the 'narrated speech event', $P^{\text {ns }}$. However, see also Kockelman (2004) and Mushin (2001) for different treatments of Jakobson's framework with respect to the evidential origo.
} 
example, in speech reports an evidential may reflect the perspective of the reported speaker (e.g., Arakaki, 2013; Forker, 2014), and events in narratives may be presented from the perspective of a central protagonist (e.g., Lawrence, 1987; McLendon, 2003; Mushin, 2001). However, to date, there has been no comprehensive cross-linguistic survey of the kinds of perspective relationships that can be expressed by grammaticised evidentials (although this issue is discussed in some detail in Aikhenvald, 2004a). Our comparative study takes a small step towards this end through focusing specifically on interrogative contexts, where for many languages the speaker perspective of an evidential in a declarative changes to addressee perspective (as construed by the speaker) in an interrogative. This is illustrated in our Duna example above, where speaker A's use of the evidential -yarua in the interrogative construction is oriented towards the addressee.

In general, we have followed source authors' terminology in regard to whether a morpheme or construction is 'evidential'. Our main focus is on languages that also fit a fairly narrow definition of evidentiality (cf. Mushin, 2001, concerning Chafe, 1986), that is, those that have grammatical morphemes (as opposed to lexical or periphrastic constructions) with information source as a primary meaning (although this is debatable in some cases). However, we do not treat obligatory marking of the category as a definitional property. In discussing questions, we deal with examples that are formally marked as interrogative, for example with an interrogative particle or pro-form. A complete study of evidentials in questions will need to go beyond clauses that have interrogative morphosyntax, and address, for example, declarative sentences that are interpreted as questions (see, e.g., Heritage, 2012; Labov and Fanshell, 1977; Quirk et al., 1989:814). Throughout the paper we use the word 'perspective' in an informal sense to talk about the point of view that an evidential appears to evoke (although we recognise that perspective-taking is attributable to myriad other linguistic phenomena besides evidentials, and that other approaches treat perspective or similar as a more rigorously defined concept to be modeled in different ways, e.g., Du Bois, 2007; Mühlbauer, 2008; Dancygier and Sweetser, 2012). We refer to the perspective-holder, that is, the person whose perceptual experience is purported to be expressed by an evidential, as the 'evidential origo'.

The remainder of this paper is structured as follows. In section 2, we survey the formal distribution of evidentials as used in interrogative clauses, illustrating the kinds of structural restrictions that apply. We find that it is unusual for all relevant markers within a single language to show the same behaviour with respect to interrogativity. This is often-but not always-a consequence of the fact that evidential marking is 'scattered' through a language's grammar rather than comprising a single paradigmatic system (see, e.g., Jacobsen, 1986; Aikhenvald, 2004a). In section 3, we turn to perspectival interpretations, discussing attested relationships between declarative and interrogative clauses. Section 4 addresses the phenomenon of egophoricity (conjunct/disjunct marking), a typological category that has been closely linked to evidentiality. 'Egophoric' markers canonically (although not exclusively) occur in statements with first person subjects and questions with second person subjects, associating with the speech act participant who is the 'epistemic authority' for a given conversational turn and bringing to the fore the question of whose knowledge is at issue. Section 5 provides a summary and concluding remarks, linking evidential interrogatives to a family of related epistemic phenomena that are characterised by perspective switching.

\section{Issues in formal distribution}

We review four attested distributional patterns of evidential marking with respect to sentence type: languages where evidential marking in interrogatives is formally unrestricted (section 2.1); those where evidential interrogatives are partially restricted (section 2.2); languages where evidentials cannot be used in interrogatives (section 2.3); and finally, those where evidentiality is marked in distinct ways according to sentence type (section 2.4 ). Section 2.5 presents a summary and discussion of certain possible generalisations.

\subsection{Formally unrestricted evidentials}

As discussed by Aikhenvald (2004a:242), in certain languages the same evidential markers that occur in declaratives can also be used in interrogatives. These are 'symmetric' systems with regard to sentence type (Miestamo, 2011). For example, the three evidential suffixes of Qiang (Tibeto-Burman) can be used in declaratives, polar interrogatives, and content interrogatives (Table 1).

Aikhenvald (2004a:242) notes that the evidential markers of Tsafiki (Barbacoan, Colombia) and Nganasan (Uralic, Russia) can all be used in interrogative as well as declarative sentences, and Duna (Duna-Bogaia, Papua New Guinea) also appears to be of this type. ${ }^{4}$ The Macedonian (Slavic) confirmative and non-confirmative evidential strategies are also

\footnotetext{
${ }^{4}$ Duna evidential markers belong to one of four (or, arguably, five) broad information source categories (see San Roque, 2008), and comprise thirteen morphemes in all (not including additional allomorphs that combine with irregular verbs). While at least one morpheme from each category is attested in both a polar and content interrogative, a few of the thirteen forms are not attested in questions at all in the available data. However, we know of no structural reason why such interrogatives could not occur (although they may be very odd pragmatically).
} 
Table 1

Qiang evidential suffixes in declaratives and interrogatives (compiled from LaPolla, 2003a, 2003b; email communications from C. Huang and R. LaPolla).

\begin{tabular}{|c|c|c|c|c|c|}
\hline & \multicolumn{2}{|c|}{$\begin{array}{l}\text { DECLARATIVE } \\
\text { 'S/he went to Chengdu' }\end{array}$} & \multicolumn{2}{|c|}{$\begin{array}{l}\text { POLAR INTERROGATIVE } \\
\text { 'Did s/he go?' }\end{array}$} & $\begin{array}{l}\text { CONTENT INTERROGATIVE } \\
\text { 'Where did s/he go?' }\end{array}$ \\
\hline $\begin{array}{l}\text { visual: } \\
-u\end{array}$ & $\begin{array}{l}\text { the: } z d z y t a \\
\text { 3SG Chengdu:LOC }\end{array}$ & $\begin{array}{l}\text { ha-qə-u } \\
\text { DIR-go-VIS }\end{array}$ & $\begin{array}{l}\text { the: ha-qə-u } \\
\text { 3SG DIR-go-VIS }\end{array}$ & $\begin{array}{l}\text { gua } \\
\text { INTER }\end{array}$ & $\begin{array}{l}\text { the: tcala kə-u } \\
\text { 3sG where go-VIS }\end{array}$ \\
\hline $\begin{array}{l}\text { inferred: } \\
-k\end{array}$ & $\begin{array}{l}\text { the: }{ }_{z} d_{z y t a} \\
\text { 3SG Chengdu:LOC }\end{array}$ & $\begin{array}{l}\text { ha-qə-k } \\
\text { DIR-go-INF }\end{array}$ & $\begin{array}{l}\text { the: ha-qə-k } \\
\text { 3SG DIR-go-INF }\end{array}$ & $\begin{array}{l}\text { gua } \\
\text { INTER }\end{array}$ & $\begin{array}{lc}\text { the: } t_{\text {cala }} \text { kə-k } & \text { gua } \\
\text { 3SG where go-INF } & \text { INTER }\end{array}$ \\
\hline $\begin{array}{l}\text { hearsay: } \\
-i\end{array}$ & $\begin{array}{l}\text { the: } z \text { dzyta } \\
\text { 3SG Chengdu:LOC }\end{array}$ & $\begin{array}{l}\text { ha-qə-i } \\
\text { DIR-go-HS }\end{array}$ & $\begin{array}{l}\text { the: ha-qə-i } \\
\text { 3SG DIR-go-HS }\end{array}$ & $\begin{array}{l}\text { gua } \\
\text { INTER }\end{array}$ & $\begin{array}{l}\text { the: } t_{6} \text { ala ha-qə-i } \\
\text { 3sG where DIR-go-HS INTER }\end{array}$ \\
\hline
\end{tabular}

attested in polar and content interrogative environments (Friedman, 2003). Thus, this facility is not restricted to a single phylogenetic group or linguistic area.

\subsection{Partial restriction of evidential interrogatives}

The use of evidential markers in interrogatives is often partially restricted so that either (i) only a subset of the possible declarative evidential markers can be used in questions and/or (ii) only some interrogative structures of the language can include evidential markers.

As an example of (i), Valenzuela (2003:40) describes how in Shipibo-Konibo (Panoan) the direct and reported evidentials occur in the same slot as the general interrogative marker, but the inferential marker does not. Thus, only inferential interrogatives are possible in this language. Another possible case is Eastern Pomo (Pomoan), where the direct, non-visual and inferential markers are attested in questions, but the reported marker is not, suggesting that this is a disallowed structure (McLendon, 2003). Partial restrictions such as these may be a consequence of the fact that, within a single language, the markers that belong to the semantic domain of information source are formally disparate (constituting 'scattered evidentiality', see Aikhenvald, 2004a). It remains to be seen how interacting factors such as the degree of grammaticisation (e.g. as inflection, clitic, particle, etc.) and the core nature of a marker's evidential meaning (e.g., as opposed to a pragmatic inference) may affect the likelihood that an evidential or evidential strategy will be possible in an interrogative structure.

As an example of (ii), polar and content interrogatives often have quite different formal properties (Sadock, 2012), and thus different combinatorial possibilities with evidentials. For example, in Jarawara (Arauan) witnessed/unwitnessed evidentiality can be expressed in polar interrogatives, but not in content questions (Dixon, 2003). The language Hup (Maku/Guaviaré-Japurá) shows a restriction that relates to both information source type and the polar/content distinction. Hup has five evidentials in declaratives: a visual/unmarked inflection, non-visual, inferential and reportative clitics, and an additional inferential suffix, -ni. The unmarked/visual and the evidential clitics are used in both polar and content interrogatives. However, while inferential -ni can occur in content interrogatives, it cannot be used in basic polar questions. This is because - $n i$ is restricted to clause-final predicates, and polar interrogatives are marked using word order inversion; the predicate is thus no longer final, and -ni becomes ungrammatical (Epps, 2008:642-662; 784-787).

Cheyenne (Algonquian) exemplifies another way that evidentials can be restricted to a subset of question structures (Murray, 2010). Here, the question marker -he competes for the same morphological slot as evidentials (compare 2a and b) and is incompatible with them. However, evidential questions can still be formed using the interrogative clitic, mó= $(2 \mathrm{c})$.

$$
\begin{array}{ll}
\text { a) é-nemene-séste } \\
\text { 3-sing-REP.3sG } \\
\text { 'He sang (reported)' } \\
\text { b) é-nemene-he Floyd } \\
\text { 3-sing-Y/N Floyd } \\
\text { 'Did Floyd sing?' } \\
\text { c) mó=é-nemene-séste } \\
\text { Y/N-3-sing-REP.3sG } \\
\text { 'Did he sing (reported)?' }
\end{array}
$$

In Ecuadorian Quechua, blocking of certain evidential interrogatives is a consequence of focus properties. The "best evidence' suffix, -mi, can affix to different constituents in a declarative clause and interacts with information structure. For example, in (3) the speaker claims to have good evidence for the keys being the forgotten object. The suffix -mi could alternatively occur on the pronoun pay, in which case the speaker would be claiming good evidence for knowing who 
forgot them. And if -mi were to occur on the final predicate, the speaker would be claiming to have best evidence for the actual act of forgetting.

(3) Ilaves-ta-mi pay kunka-shka

keys-ACC-EV 3 forget-PTCP. 3

'He's forgotten his keys.'

In content interrogatives, however, the focus properties of -mi mean that it is restricted to occurring on the question word itself (4a) and is judged ungrammatical if affixed to other constituents in the clause (4b-c). (See also Faller, 2002a:229.)
a) May-man-mi llaves-ta
apa-rka-nki?
where-ALL-EV keys-ACC take-PAST-2
Where did you take the keys?
b) *May-man llaves-ta-mi apa-rka-nki?
where-ALL keys-ACC-EV take-PAST-2
$\begin{array}{lll}{ }^{*} \text { Mayman } & \text { llaves-ta apa-rka-nki-mi? } \\ \text { where-ALL } & \text { keys-ACC }\end{array}$

In polar questions, the evidential -mi competes for the same morphological slot as the interrogative marker -chu, so these forms cannot co-occur. (However, -chu is not obligatory in polar questions and a 'question' reading can still be obtained from a sentence that is morphosyntactically indistinguishable from a declarative.)

The languages discussed so far illustrate that the question of whether evidentials occur in questions rarely has a simple answer. In different languages, different information source types (e.g., as in Shipibo-Konibo v. Eastern Pomo) and different question types (e.g., as in Jarawara v. Quechua) are barred from participating in evidential interrogative structures. Thus, even in a preliminary survey of 'basic' polar and content interrogatives, we find complex interactions of morphosyntactic, modal, and information structure constraints, and much cross-linguistic variability.

\subsection{No evidentials in interrogatives}

In certain languages the co-occurrence of evidential and interrogative structures is not partially restricted, but completely blocked. This situation appears to be quite rare cross-linguistically; just how rare is difficult to assess definitively, as descriptive works are very unlikely to include an exhaustive list of examples that illustrate the incompatibility of each evidential marker with each possible interrogative type. Nevertheless, several scholars have made clear statements concerning the impossibility of evidentials in interrogative structures. In regard to Enets (Samoyedic), Künnap states that " $[$ t]here are not evidentials in interrogative clauses" (2002:149), and Aikhenvald (2004b:11) notes that this is also the case in most other Samoyedic languages. Chirikba (2003:254-255) describes how the Abkhaz evidential (an inferential construction) is not possible in interrogatives because it involves a finite verb form, and interrogatives are based on non-finite verb forms. ${ }^{5}$

The fact that evidential markers occur in the same morphological slot as interrogative markers in some languages suggests a relationship between information source and sentential mood. In describing Jaqaru (Aymaran), Hardman (1986:129-130) notes that evidentials and interrogative markers form a set of contrasting sentence types and states that interrogative suffixes can be thought of as part of the evidential paradigm in that "they state specifically that the speaker does not have the information". Example (5) shows the content interrogative (a), polar interrogative (b), personal knowledge (c) and reportative (d) "data source" suffixes. An implication (not explicitly discussed by Hardman, 1986 or Hardman, 2000) is that evidential and interrogative marking do not co-occur. ${ }^{6}$
a) Qamisha-sa
'How is X?'
b) Amrucha-txi
'Is X well?'

\footnotetext{
${ }^{5}$ However, Chirikba (2003) notes that this does not exclude the possibility of evidentially marked sentences being used to form 'echo questions' with the clitic ba, utterances which imply that the questioner is not sure he has correctly heard the addressee's prior statement, and/or is seeking confirmation (Hewitt, 1979:22); see also Kehayov (2008). If these are considered a subtype of interrogative then Abkhaz would seem to be an example of a language that has partially rather than completely restricted interrogatives.

${ }^{6}$ Hardman (1986) describes the Aymaran language Aymara in similar terms. However, Coler's (2014) work on the Muy'laq Aymara variety of the language identifies a different set of morphemes as 'evidentials', and maintains that at least some of these do occur in interrogative contexts.
} 


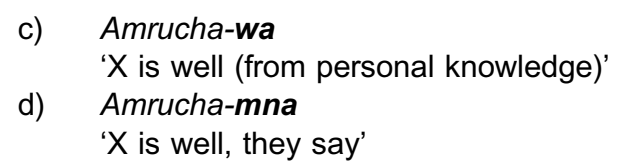

(Jaqaru, Hardman, 1986:129)

Languages such as Abkhaz and Jaqaru represent an extreme kind of 'asymmetry' in that evidential distinctions that can be made in declaratives cannot be made in interrogatives (although an alternative way of viewing the Jaqaru case is that 'interrogative' is actually a subtype of evidential). The systems described in the following section exemplify a different kind of asymmetry, whereby the category is marked in different sentence types by different formal means.

\subsection{Special interrogative evidentials}

Certain languages have interrogative evidential marking that is distinct to that used in declaratives (although the two may be transparently related). One of the best-described cases is that of Tariana (Aikhenvald, 2003; see also Malone's (1988) description of a similar situation in Tuyuca). An example of a non-visual question-answer pair from Tariana is shown in (6). The non-visual marker -tha in the interrogative is responded to using the non-visual affirmative -mha.

(6) A: pi-na-tha litena

2SG-want-PRES.SENS.INTER more

'Do you want more?'

B: nu-na-mha

1SG-want-PRES.SENS

'Yes, I do (lit. I want).'

(Aikhenvald, 2003:314)

Table 2 shows the (recent) past Tariana evidential markers from the affirmative and interrogative systems. The number of evidential choices is reduced from five in statements to three in questions. The two systems may be somewhat in flux, as Aikhenvald (2003:317) notes that younger speakers sometimes use affirmative evidentials in content questions.

Table 2

Tariana (recent) past evidentials (compiled from Aikhenvald, 2003:289, 311; 2004a:86).

\begin{tabular}{llll}
\hline & $\begin{array}{l}\text { Affirmative } \\
\text { (recent past) }\end{array}$ & $\begin{array}{l}\text { Interrogative } \\
\text { (past) }\end{array}$ & \\
\hline VISUAL & $-k a$ & $-n i h k a$ & VISUAL \\
NON-VISUAL & $-m a h k a$ & $-m h a$ & NON-VISUAL \\
(SENSORY) & & & (SENSORY) \\
INFERRED & - -nihka & - sika & INFERRED \\
ASSUMED & - sika & & \\
REPORTED & - pidaka & & \\
\hline
\end{tabular}

For Tariana, it seems that the declarative/interrogative split occurs because information source and speech act are indicated as a portmanteau category, reiterating the close relationship between evidentiality and mood as mentioned in the previous section.

Another example of a 'split' evidential system is seen in Foe (Papua New Guinea), described by Rule (1977) as marking up to six evidential distinctions on verbs. For nearly half of the Foe paradigm, the markers used in polar and content interrogatives differ (in systematic ways) from those used in declaratives. For example, the far past visual marker is -bo'owa'ae in a declarative, and -bo'oriye in an interrogative, as shown in (7). The morpheme -be is a general interrogative marker that occurs in all polar interrogatives, suggesting that the interrogative evidential is not in itself sufficient to mark sentence type. ${ }^{7}$

(7) A: yo hera wa-bo'oriye-be

3SG yesterday come-FP.VIS.INTER-INTER

'Did he come yesterday (seen)?'

\footnotetext{
7 The marker -be is transparently similar to the interrogative marker of neighbouring languages from the Engan family, and is probably borrowed from them (cf. also Duna -pe, likely to have been borrowed from Duna's Engan neighbour, Huli). It seems possible that the Foe markers originally consisted of an evidential or tense element in combination with an erstwhile sentence type or mood marker. As the Engan question marker took hold, the Foe markers were reanalysed as non-compositional tense/evidential inflections.
} 

B: Ao! yo hera wa-bo'owa'ae
yes 3sg yesterday come-FP.vis
'Yes! He came yesterday (seen).'

(Foe, Rule, 1977:86, our gloss)

Duna, spoken in the same broad region as Foe (where the evidential systems of New Guinea are concentrated), also has distinct constructions for at least some evidential categories in interrogatives as opposed to declaratives. However, these are optional rather than the only possibility for evidential questions (see San Roque, 2008:378-379).

Finally, we note that Jacobsen (1986:16-19) describes the presence of special interrogative quotative/indirect constructions in Makah, while Waldie (2012) provides in-depth discussion of a similar situation in Nuu-chah-nulth (both Wakashan languages). Example (8) from Makah illustrates the hearsay marker -wa:t (which is incompatible with interrogatives, as are other evidential suffixes in the language). Example (9) shows that a hearsay contrast can be expressed in questions by substituting the marker -i:'ča for the third person ending -a:ł. The form -i:'ča is also used in subordinate and counterfactual clauses, and it seems likely that the construction exemplified is an evidential strategy rather than a dedicated marker of information source.

(8) a) $\quad$ xu·bit'adib?u 'He was snoring'

b) $\quad x u \cdot b i t$ 'adibit wad 'He was snoring (I was told)'

(Jacobsen, 1986:16)

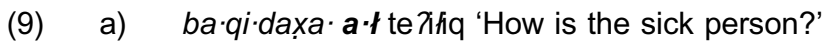

b) ba.qi.daxa.i-ča te Xifiq 'How did he say the sick person is?'

(Jacobsen, 1986:19)

Evidential systems that 'split' according to sentence type are thus found in diverse parts of the world. For all cases that we are aware of, the languages in question have complex systems in that they mark at least three evidential distinctions in declaratives; however, the number of distinctions is always reduced in interrogatives (e.g., as in Table 2). For Tariana and Foe, the declarative and interrogative evidential forms share at least some content (e.g., bo'o in the Foe visual markers), but this is not so for Makah. The Makah case suggests that, where evidential and interrogative markers are incompatible, speakers may find a 'workaround' to express contrasts that are available in declaratives by other means (see also the Guambiano data discussed in section 4.2.4).

\subsection{Formal distribution: summary and discussion}

Table 3 summarises major distributional patterns of evidential markers with respect to declarative and interrogative sentence types. (Note that we focus here on possible formal combinations, not on whether the resultant construction does or does not function as a typical information question.) Languages can be symmetrical (either evidentiality is not marked at all, or the same evidentiality markers are equally available in both sentence types, as represented by an equals sign, =), or asymmetrical, either excluding evidentiality from one sentence type, or having more evidential possibilities in one than the other (as represented by the 'greater/less than' sign, >). Languages that mark evidentiality in interrogatives, but with some restrictions, are probably the most common type, so that in general fewer evidentiality choices are found in questions than in statements (Aikhenvald, 2004a:242).

Table 3 shows that asymmetry appears to be unidirectional, in that we know of no language which has more evidential choices for interrogatives than for declaratives, or where evidentiality is only marked in interrogatives. Intuitively, this kind of situation appears unlikely, but we note two points. First, the much-discussed association between evidentiality and epistemic modality suggests a pathway whereby an information source marker could become a proxy for indicating a questioning speech act, for example, in a similar way to the 'uncertainty' marker of Matses (Panoan) that is associated with

Table 3

Evidential contrasts in interrogatives and declaratives.

\begin{tabular}{llll}
\hline & Evidential contrasts & Attested & Example language(s) \\
\hline Symmetrical & No grammaticised evidential & + & English, Mandarin, Maori (de Haan, 2013) \\
& Declarative $=$ interrogative & + & Qiang, Duna \\
Asymmetrical & Declarative $>$ interrogative & + & SAME MARKERS: Hup, Quechua \\
& DiFFERENT MARKERS: Foe, Tuyuca \\
& Declarative only & + & Abkhaz, Jaqaru \\
Interrogative $>$ declarative & - & \\
& Interrogative only & - & \\
\hline
\end{tabular}


polar interrogatives (Fleck, 2003:292), or the 'speculative' morpheme in Shipibo-Konibo that forms self-directed questions (Valenzuela, 2003:47-49; see also Boye, 2012:52). Related phenomena are the Novo Selo 'nonconfirmative' evidential that is reported to be "especially common" in questions (Mladenov, 1969, as cited in Friedman, 2003) and the Tucanoan interrogative forms that are argued to derive from an inferential/mirative construction (Idiatov and van der Auwera, 2008). Secondly, it seems possible that a non-declarative, minor sentence type could encode specific information source semantics that do not have a declarative counterpart. For example, the 'potential observation' marker in Duna indicates that an addressee could have visual information for something. Clauses marked with this morpheme do not share key formal features of Duna declarative clauses, and generally function as questions (San Roque, 2008).

While for the majority of languages at least some evidentials are formally compatible with interrogatives, this is not to say that such combinations are necessarily common in discourse. Evidential interrogatives have been reported to be relatively infrequent items, even where they are formally unproblematic (e.g., Yukaghir, Maslova, 2003; Western Apache, de Reuse, 2003), and probable low frequency can be inferred from the fact that many descriptions of languages with evidentials do not include explicit discussion of their occurrence in interrogatives. In a sample of 80 interrogative clauses from Duna conversational data (in utterances concerning past time events, where evidential contrasts are the most numerous), evidential markers were used in 31 instances, or $39 \%$ of the time, compared with a sample of 74 declaratives, where 43 clauses (58\%) were marked with evidentials. This small sample thus suggests that evidential markers in Duna conversation are likely somewhat more frequent in statements than in questions.

As already mentioned, one motivation for lower frequency of evidential interrogatives may be the mismatch between the typical evidential domain (expressing how something is known) and the typical interrogative domain (trying to find out something that is not known). Other factors that may affect frequency are the possible difficulties of making specific claims about addressee knowledge and the (perhaps consequent) conventionalisation of certain evidential interrogatives as pragmatically specialised question types. These issues are discussed further in the following section.

\section{Perspective}

Evidentials are perspectivising in that they present an event from the point of view of an evidential origo. For some evidential markers in some languages, speaker-anchored perspective is the default in both declaratives and interrogatives (section 3.1). In many cases of interrogative evidentials, however, the identity of the perspective-holder shifts from a typical, declarative interpretation of speaker to that of the addressee (section 3.2), ${ }^{8}$ whereas for others, either speaker or addressee perspective can be evoked (section 3.3). Section 3.4 briefly reviews several other perspective relationships, including those that are associated with special speech act types, and those where speaker perspective is not the default interpretation for declarative clauses. Section 3.5 gives a summary and discussion.

\subsection{Speaker perspective maintained in interrogatives}

In some languages, evidentials in interrogatives, as in declaratives, will be understood as giving the speaker's 'take' on the described event. Aikhenvald (2004a:244) notes that the maintenance of speaker perspective in interrogatives is "somewhat rarer" than other possibilities. Declarative (10) and interrogative (11) examples from Eastern Pomo show the interpretation of the non-visual sensory inflection -ink'e is consistently interpreted as reflecting the speaker's information source.

ba· háyu-he?mi'-p' $k^{h}$ é·š ka·Núl-ink'e du·we

that dog-3SG-M.AGENT lots talk/bark-SENS last.night

'The dog was barking last night (I heard it).'

(McLendon, 2003:103)

kiyá=t'a Zéc-ink'e?

who=INTER Sneeze-SENS

'Who sneezed? (I heard, but don't know who sneezed).'

(McLendon, 2003:115)

Yukaghir marks indirect (inferential) evidence (12), contrasting with a direct/unmarked construction. Maslova (2003) notes that inferential evidentiality is very rarely marked in interrogatives, but that, when it does occur, it reflects the perspective of

\footnotetext{
${ }^{8}$ This itself can be understood as a kind of "complex perspective" (see Evans, 2007), as the speaker may simultaneously imply their own epistemic stance towards an event through the very act of questioning; see Bergqvist (this issue) concerning the presence of speaker epistemic perspective in utterances that ostensibly purport to encode addressee epistemic perspective.
} 
the speaker, as in declaratives. In (13), "the Inferential indicates that the speaker has not witnessed people going away from his current location" (Maslova, 2003:228).

tan me:me: naha: motlorqo-j-ben=no:-l'el

that bear very thin-ATTR-NR=COP-INF(INTR:3SG)

'That bear was very thin (as can be seen from his traces).'

(Maslova, 2003:222)

$$
\begin{aligned}
& \text { qodo ti:-t kebej-nu-l'el-ni? } \\
& \text { how here-ABL go-IPFV-INF-3PL:INTR } \\
& \text { 'How do people go away from here?' }
\end{aligned}
$$

(Maslova, 2003:228)

Examples (14) and (15) illustrate the reported marker, néh ${ }^{1}$, in Sochiapan Chinantec (Otomanguean). In a declarative, né ${ }^{1}$ indicates that "the speaker is passing on secondhand information", and in an interrogative it "implies that the speaker is puzzled by something that s/he has heard" (Foris, 1993:544). From Foris' description, an example such as (17) may be more like a conjectural question than an information-seeking question (see section 3.4.2).

$$
\begin{aligned}
& L^{3} \quad n \dot{t}^{2} \quad n e ́ h^{1} \quad t^{2} \quad j u a ́ h^{23} \quad t^{2} a^{2} \text { daun }{ }^{32} \\
& \text { idea that REP DISC say.TI.PRES.3 old.person } \\
& \text { 'That, it is said, is what the old people used to say.' }
\end{aligned}
$$

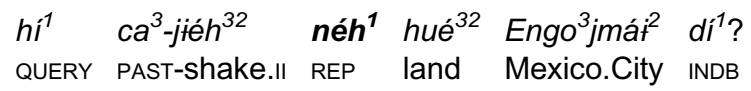

'Did Mexico City have an earthquake (as I/we have heard)?'

(Foris, 1993:544)

According to examples in Friedman $(2003,2004)$, the Macedonian non-confirmative evidential (which can express inference, report, doubt and/or surprise) is typically interpreted with speaker perspective in both statements and questions (although see also section 3.3). Other examples of languages where evidential marking in interrogatives reflects the speaker's information source are Bora (Aikhenvald, 2004a:244), and possibly Shipibo-Konibo (inferential and reported markers, Valenzuela, 2003:46) and Jarawara (witness/non-witness distinction, Dixon, 2004:203).

Examples (10)-(15) suggest that the speaker as evidential origo is a stable component of the meaning of information source markers (see also Waldie, 2012); we could think of the evidential as being 'speaker-anchored' in much the same way as a demonstrative such as English here is speaker-anchored (always allowing that the 'speaker' may be transposed to a reported speaker, and noting that many scholars find spatial anchoring inadequate to characterise demonstratives, see e.g. Enfield, 2003; Hanks, 1990, 2005). Such examples support a deictic view of evidentiality.

Most (but not all) examples of speaker perspective questions that we have found in the cited literature are content interrogatives (see, e.g., 11 and 13). This is striking given that polar questions are suggested to be much more frequent than content questions cross-linguistically (Stivers et al., 2010). It seems possible that speaker perspective will be more compatible with content questions than with polar questions as, for the former, the reality of the event is to some extent presupposed by the speaker. It is perhaps in these situations-where a speaker knows that an event has happened (e.g., they saw John hit someone), but does not know all the details (e.g., whom John hit)-that we can most easily imagine a question that spells out the information source of the speaker.

\subsection{Addressee perspective in interrogatives}

Evidentials in interrogatives can 'flip' to reflect the addressee's information source, or rather, the addressee's information source as framed by the speaker. Changing from the speaker as the perspective-holder in statements to the addressee in questions is the most common pattern for evidentials cross-linguistically. The phenomenon is illustrated in examples (16-17) from Duna, taken from a text where the speaker describes a frightening incident from his childhood. While he and his little brother were home alone, a strange storm blew up and a supernatural creature broke into the house and attacked his little brother. The speaker was a direct witness of this attack, and describes it using a visual evidential (16).

(16) eh, nane no keni khete=na sutia

hes boy 1sG brother small=SPEC strike.PFV.VIS

'Ah, something struck the boy, my little brother (I saw).'

Later, the speaker's mother returns home and asks him what happened to his brother. Her question is represented in the text as free direct speech (17a). The mother expects that her elder son was a visual witness to the events, and thus uses a 
visual evidential in her question, taking the anticipated perspective of her addressee. In his response to this question (also relayed as direct speech), the speaker again uses the visual evidential, confirming his mother's assessment of the information source he has for this event (17b).
a) ai-ka sutia?
who-ERG strike.PFV.VIS
'Who struck him (you saw)?'
$\begin{array}{llll}\text { b) } a, & \text { yiAo } & \text { honene-ka=rape } & \text { sako } \\ \text { ah } & \text { nothing } & \text { thing-ERG=UNC } & \text { be.confused } \\ \text { makura-na } & \text { si } & \text { wa-ye } & \text { sutia } \\ \text { club-SPEC } & \text { hold } & \text { come-DEP } & \text { strike.PFV.VIS }\end{array}$
'Ah, something, I don't know what it was, brought a club and hit him (I saw).'

The supposition implied by the use of a visual evidential in an interrogative-that the addressee has witnessed the sceneis made explicit in the real-life exchange shown in (18). The speaker (D) uses -tia 'vIs' in asking her daughter (R) where another relative has gone. In her response speaker $R$ rejects the terms of D's question, asserting that she has not seen Joshua.

$$
\begin{aligned}
& \text { D: Jotua pa-na ngutia } \\
& \text { PSN QUERY-SPEC gO.PFV.VIS } \\
& \text { 'Where has Joshua gone (you saw)?' } \\
& \mathrm{R} \text { : Jotua no na-ke-ya=nia } \\
& \text { PSN 1SG NEG-See-NEG-ASSERT } \\
& \text { 'I didn't see Joshua.' }
\end{aligned}
$$

Example (19) shows an interrogative from Wintu (Wintuan) that uses a non-visual evidential, and (20) shows a Magar (Tibeto-Burman) interrogative formed with the inferential marker -sa. In both cases, the speaker anticipates the kind of evidence that is available to the addressee, that is, they purport to take the perspective of the hearer.

$$
\begin{aligned}
& \text { Henuni mis yilla-kint }{ }^{\text {heri-? }} \\
& \text { how you send-SENS.INTER } \\
& \text { 'How did he instruct you (in your hearing)?' }
\end{aligned}
$$

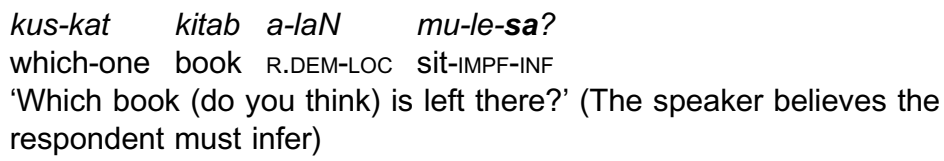

(Grunow-Hårsta, 2007:163)

A question-answer pair (21) from Gitksan (Tsimshianic) illustrates addressee perspective in an interrogative that is marked as reportative, while the declarative response illustrates speaker perspective with the same marker. The scenario is that Speaker A and B are about to go on a trip together, for which Speaker B booked the tickets.

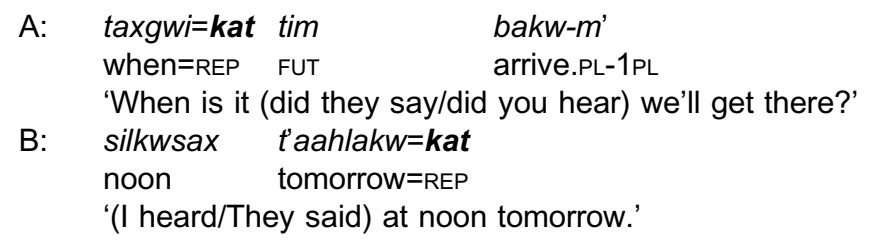

The examples of special interrogative marking discussed in section 2.2 also illustrate perspective shift for sensory, visual, and reported evidentiality. As far as we know, all languages that have special interrogative evidential morphology also practice interrogative perspective shift.

As mentioned previously, evidential marking has been reported to be less frequent in interrogatives than in declaratives. In regard to Tariana (and, by extension, other languages where perspective flip is the norm), Aikhenvald (2004a) suggests that one pro-social reason for avoiding evidential interrogatives is that such questions are "dangerous" in that they express a specific assumption about the addressee's knowledge, and this may be felt as a kind of trespass 
(see also Levinson, 2012 on the "potential social costs" of asking questions cross-linguistically). A question that is marked with an evidential may also be 'coercive' (cf. Stivers and Rossano, 2010, 2012) in that it projects a very particular kind of response, essentially putting morphemes into the addressee's mouth. ${ }^{9}$ (However, it seems likely that these kinds of considerations could have very different effects in languages where evidential markers are obligatory as opposed to those where they are optional.)

While it may be risky, for at least some languages it has been claimed that a shift from speaker to addressee perspective is an obligatory component of evidential interrogatives (e.g., Lim, 2011:429 in regard to Korean; Garrett, 2001 in regard to Tibetan; see also Anderson, 1986:277-278). Such cases suggest that the identity of the evidential origo is predetermined and predictable from sentence type: it is the speaker in a declarative, and the addressee in an interrogative. However, for many languages it is not clear whether the identity of the evidential origo is inferable from formal sentence type, or whether it is more of a "standard implicature" (Levinson, 1983; see also Boye, 2012:271-273, McCready, 2007). ${ }^{10}$ That is, speaker and addressee are the default perspective-holders in statements and questions, respectively, but other configurations (e.g., addressee perspective in declaratives) are also possible, given the right pragmatic circumstances. Under this latter scenario, identifying the evidential origo is an issue of "pragmatic resolution" (see Levinson, 2004), as we usually expect to make statements about our own knowledge, and ask questions about others' knowledge (see also Heritage, 2012; Kamio, 1997; Labov and Fanshell, 1977; McCready, 2007).

\subsection{Speaker or addressee perspective}

While certain evidentials seem to require, or at least strongly predict, the adoption of one particular perspective in interrogatives, we also find cases where either speaker or addressee perspective are viable interpretations (e.g., Macedonian as described by Friedman, 2003:201-202). These can be thought of as gradiently rather than categorically distinct from languages where a certain perspective is the default, but is not obligatory. In such cases, the relationship of the addressee to the proposition expressed may be a crucial factor in determining how the interrogative is interpreted.

Duna visual, sensory and results evidentials in interrogatives are typically (although not necessarily) understood as taking addressee perspective (see 1 and 17, above). However, the 'reasoning' evidential shows a distinct pattern in that, while it typically takes speaker perspective in declaratives, interrogatives are readily interpreted as having either addressee or speaker perspective. Example (22) illustrates the reasoning evidential in a declarative: it indicates that the speaker has 'figured out' something, and usually implies that he or she is surprised that this situation is the case. In this instance, the speaker has just observed a non-Duna person correctly respond to a command given in Duna.

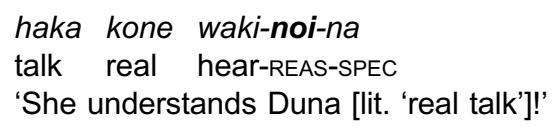

Examples (23-24) illustrate a hypothetical scenario where it would be appropriate to use the reasoning evidential in an interrogative. The speaker (Annabel) is at the house of a friend, Jenny. While Jenny is out of the room, Annabel notices an empty medicine packet on the table, and asks her companion (Sarah) whether Jenny has been sick. There are two possible interpretations of the reasoning marker. In a situation where Sarah has arrived with Annabel, and Annabel thus assumes that the same evidence is available to both of them, the evidentially marked interrogative is understood as having addressee perspective. With her question, Annabel in a sense 'directs' Sarah to make a reasoned inference concerning Jenny's health. In this imagined situation, Sarah co-operates with this agenda, and her response also uses the reasoning marker (23).

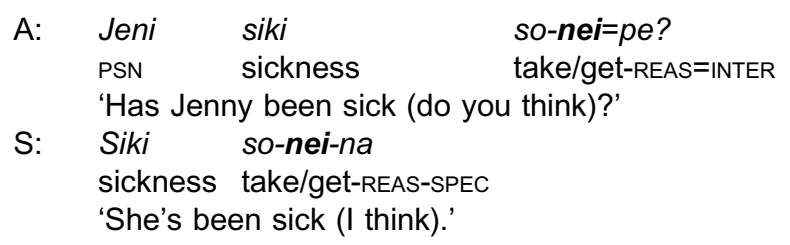

\footnotetext{
${ }^{9}$ We note that the suitability of an addressee perspective evidential interrogative is likely to be especially contingent on sequential context, as whatever the addressee has just said could 'set the stage' for subsequent turns that orient towards addressee knowledge.

${ }^{10}$ A formal explanation that has been proposed for perspective flip is that questions contain 'monstrous' operators (in the sense of Kaplan, 1989) that manipulate context (Schlenker, 2003). These apply to an index that Lasersohn (2005) and McCready (2007) call the 'judge' (a role that could be understood to subsume evidential origo).
} 
Alternatively, Sarah is a member of Jenny's household. In this case (24), Annabel does not expect Sarah to assess the proposition based on reasoning evidence, as Sarah will have more direct knowledge of Jenny's state. The reasoning evidential here retains speaker perspective, and expresses Annabel's surmise and surprise that Jenny may be ill, as this was not something she expected. Sarah's response uses an unmarked perfective form, which typically implies close personal experience of an event and is more appropriate to her status as someone who lives with Jenny.

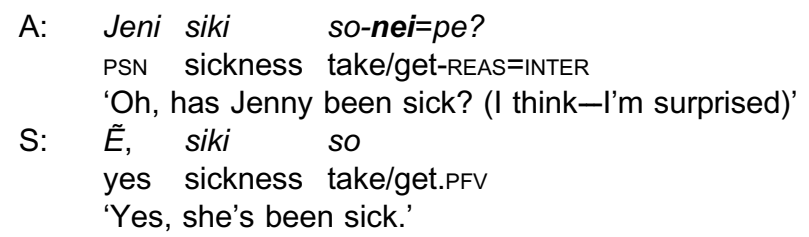

LaPolla (2003b:207-208) notes that the inferential particle in Qiang is used in questions where the speaker "assumes the addressee [...] does not have visual evidence", that is, reflecting the perspective of the addressee (25). However, where the subject of the interrogative clause is second person, the inferential marker is understood to be speaker-oriented, and "represent[s] a guess about some aspect of the situation" (26).

the: ha-qə-k gua

3SG DIR-gO-INF INTER

'Did he go?' (speaker assumes addressee does not have visual evidence)

$$
\begin{aligned}
& \text { 2ũ zdzyta: ha-qә-k-ən dza } \\
& \text { 2sG Chengdu:LOC DIR-gO-INF-2SG INTER } \\
& \text { 'Did you go down to Chengdu?' (speaker makes a guess) }
\end{aligned}
$$

Where the visual marker occurs in questions with an addressee subject, it is similarly interpreted as representing speaker perspective (27).

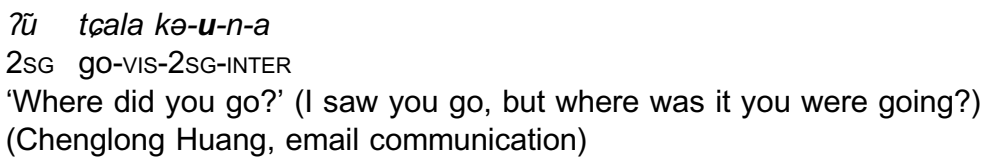

In both the Duna and the Qiang case, the relationship of the addressee to the queried proposition is important to how the evidential is interpreted. Where the addressee is not closely involved in the situation, the evidential can be unproblematically understood as referring to the addressee's inferential (or visual) knowledge. Where the addressee is connected to the situation in such a way that visual or inferential knowledge is not appropriate (e.g., they are the subject, or an intimate associate of the subject), the evidential is better interpreted as referencing speaker perspective.

\subsection{Other perspective relationships}

In this section, we present a selection of other attested perspective relationships in interrogative evidentials to show the potential for semantic and pragmatic variability in these structures. Sections 3.4.1-3.4.3 illustrate how evidential interrogatives are used in specialised question types (see, e.g., Aikhenvald, 2004a) with specific perspectival interpretations. Section 3.4.4 reminds us that, although this paper focuses on evidentials for which speaker perspective is the default interpretation for declarative clauses, there are also other possibilities.

\subsubsection{Self-directed questions}

In Ecuadorian Quechua the 'best evidence' marker -mi typically takes addressee perspective in interrogatives. It is thus restricted to contexts in which the speaker can reasonably claim some knowledge about the addressee's information source (for example, when a speaker is querying the location of an object that he has seen earlier in the addressee's possession). However, while typical information-seeking questions with -mi are possible, in a sample of several hours of recording, questions marked with the direct evidential -mi were almost exclusively self-directed, as in (28), where the speaker tries to remember something used for curing maladies. In such examples the speaker simultaneously displays ignorance (as a questioner) and knowledge (as an addressee). 


$\begin{array}{llll}\text { Kutin } & \text { shuk-ka } & \text { ima-mi? } & \text { ima-mi? } \\ \text { again } & \text { one-TOP } & \text { what-EV } & \text { what-EV }\end{array}$

'Another one, what is it? What is it?

Ima-ku-pash tiya-n-Ila-mi jampi-pa-pash

what-DIM-also exist-3-LIM-EV cure-for-also

Something else exists, for curing.'

Self-addressed questions represent a special pragmatic situation where questioner and responder are one and the same; the perspective of the addressee evoked by the evidential is, in a sense, also that of the speaker. This situation is free of the usual practical and interpersonal hurdles of the interrogative flip, as it only involves making claims about one's own information source rather than that of another (although, see Gawne, 2013 concerning self-directed questions in Lamjung Yolmo (closely related to Standard Tibetan) as targeting 'other' selves).

\subsubsection{Conjectural questions}

A specialised function of evidential questions noted in the literature is the combination of interrogative marking and inferential evidentiality to indicate that the speaker is 'wondering' about something. Littell et al. discuss these utterances as 'conjectural questions', for which the answer is "not known to the Speaker or the Addressee, and they both also think that the other does not know the answer" (2010:96). Conjectural questions invite, but do not require, an answer from the addressee. Example (29) from St'át'imcets (Lillooet Salish) shows a statement that is marked for inference with the clitic $=k^{\prime} a$. Example (30) shows an ordinary content question that is unmarked for evidentiality (a) and a contrastive conjectural question, which includes the inferential clitic (b).

$$
\text { ts'aqw-an'-ás=k'a=tu7 } k=\text { Lenny ti=kíks-a }
$$

eat-DIR-3.ERG=INF=then $D E T=$ Lenny $D E T=$ cake-EXIS

'Lenny must have eaten the cake' (upon looking in the fridge and discovering there is none left)

(Matthewson et al., 2007, as reproduced in Littell et al., 2010:97)
a) swat ku=Ihwál-ci-ts-as ti=ts'úqwaz'=a
who DET=leave-APPL-1SG.OBJ-3ERG DET=fish=EXIS
'Who left me this fish?'
who=SBJV=INF DET=leave-APPL-1SG.OBJ-3ERG DET=fish=EXIS
'I wonder who left me this fish?'
b) swát=as=k'a ku=lhwál-ci-ts-as ti=ts'úqwaz'=a

(Littell et al., 2010:90)

Littell et al. provide examples of conjectural questions formed as inferential interrogatives in St'át'imcets, Nłe?kepmxcín (Thompson Salish), Gitksan, and Cuzco Quechua. They speculate that this is a common pattern and that only relatively 'weak' (i.e., indirect) evidentials can be employed in this way (cf. also Aikhenvald's (2003:319) description of inferentially marked questions in Tariana that display speaker lack of knowledge rather than request information). If this is true, it suggests that 'straightforward' questions with addressee perspective may be dispreferred for inferential evidentials (see section 3.5). Instead, these structures can be used to imply that neither participant in the speech situation has knowledge of the proposition, and it is thus a matter for shared conjecture. The perspectival relationship in this case can be analysed in at least two ways. If we maintain a strict definition of evidentials as marking information source, then the issue becomes moot: no-one is actually claimed to have inferential evidence in this situation, and there is, therefore, no evidential perspective to identify. Alternatively, if we consider the more general sense of 'epistemic distance' that the inferentially marked question appears to convey, the perspective is the speaker's and possibly also the addressee's (see Evans, 2007 concerning 'multiple perspective' constructions more generally).

\subsubsection{Relayed questions}

Faller (2002a) describes another situation where we can understand an evidential in an interrogative as having two perspectival interpretations, similar to examples discussed in section 3.3. In Cuzco Quechua, an interrogative marked for reported evidentiality can be interpreted as reflecting addressee perspective in the typical way (31), that is, the speaker "expects the hearer to have reportative evidence for his or her answer" (2002a:230).

(31) Pi-ta-s Inés-qa watuku-sqa

who-ACC-REP Inés-TOP visit-PTCP

'Who did Inés visit (according to what you've been told)?'

(Faller, 2002a:230) 
Alternatively, a speaker can use the reported marker to 'relay' a question asked by somebody else. Thus, the same sentence would also be appropriate where Speaker $C$ has said 'Who did Inés visit?', intending B as the addressee. Speaker A repeats the question to B, with the addition of the reported marker (32).

$$
\begin{array}{lll}
\text { Pi-ta-s } & \text { Inés-qa } & \text { watuku-sqa } \\
\text { who-ACC-REP } & \text { Inés-TOP visit-PTCP }
\end{array}
$$

'(Someone said to you, ) who did Inés visit?'

(Faller, 2002a:230)

In the relay case (32), the perspective is in one sense anchored to the speaker, but the perspectivising operates at locutionary meta-level: Speaker A is expressing her 'source' for the question as an utterance (i.e., it is a report of speaker C's words), without any reference to evidence for the proposition that is conveyed in the question (i.e., Inés' visit). Johanson (2003:286) comments on similar alternation in Turkic languages, and Aikhenvald (2004a:248) describes reportatives in Kham (Tibeto-Burman) as operating like Quechua example (32). This phenomenon taps into the common dual function of reportative morphemes as both evidentials and quotative markers (cf. Guldemann, 2008). In the relay interpretation, the reportative marker functions as a quotative that indicates reported speech rather than as a marker of information source. Thus, as with conjectural questions, one could claim that relayed questions do not have a true evidential origo to identify. The behaviour of a so-called 'reportative' marker in questions could be diagnostic for whether its primary meaning is the expression of information source (in which case, we would expect the more narrowly scoped addressee perspective interpretation in a question) or reported speech (which predicts the 'relay' interpretation). If only a 'relay' interpretation is possible, this could be an argument for treating the marker as a quotative rather than as an evidential.

\subsubsection{Evidentials that do not express speaker perspective in declaratives}

The perspective relationships we have illustrated throughout this section show some complexity and variation, but the markers in question share the common feature of taking speaker perspective as a default in declarative clauses. While this is the limit of our scope in this paper, we note that it is only the tip of the iceberg in understanding the range of perspectival possibilities that may be found in evidential systems. In some evidential constructions, for example, the evidential origo is indexed through person marking, and can vary in declaratives (e.g. Nanti, Michael, 2008). It is possible for both speaker and addressee perspective to be expressed in evidential markers (e.g. Kroeker, 2001; Madden, nd), or for evidentials to evoke an unspecified or impersonal perspective (e.g., Dalabon, Evans, 2010; Duna, San Roque, 2008). Furthermore, in many languages it is possible to stack two evidentials (typically embedding one evidential within a reported evidential structure), so that there are two distinct perspectives represented. For most of these cases there is currently little information available on what happens in interrogative clauses (although, see San Roque, 2008 concerning the use of impersonal evidentials in conjectural questions).

\subsection{Perspective relationships: summary and discussion}

The perspective relationships discussed in the preceding sections, in combination with the special evidential interrogative functions exemplified, are summarised in Table 4.

Is it possible to make cross-linguistic generalisations concerning which evidentials might be especially likely to exemplify particular perspective relations in questions? It would be premature to make strong claims, but the data do suggest hypotheses. These relate to the notion of evidential hierarchies (Barnes, 1984), whereby different information source markers are understood to be ranked 'higher' or 'lower' on a (language specific) hierarchy of preference. For example, if a speaker who has both seen and heard an event chooses a visual evidential to describe that event, this indicates that visual evidence is ranked higher than other sensory evidence for that language, at least in relation to the preferred linguistic encoding. In general, the 'higher' end of the hierarchy represents evidence that is more direct, correlating with greater reliability (although the directness-reliability relationship is not always a given, see, e.g., Matthewson et al., 2007). Thus, while not necessarily universal, a typical ordering on an evidential hierarchy is something like participation > vision > other sensory experience > inference/report (see Barnes, 1984; Faller, 2002b; Oswalt, 1986 for examples and discussion). ${ }^{11}$

\footnotetext{
${ }^{11}$ Such a hierarchy does not necessarily make claims about the cultural value that may be attached to different kinds of evidence nor to what will always be selected as the most fitting evidential marker in all contexts. For example, Hill (2013:48-50) discusses an example in which a Lhasa Tibetan speaker chooses a visual-sensory evidential over a more expected personal knowledge evidential when countermanding another's assertion, foregrounding that he has recently witnessed the disputed state of affairs (see also Aikhenvald, 2004:316; Bendix, 1993:240; Schlichter, 1986:57, inter alia).
} 
Table 4

Perspectival interpretations of evidentials in interrogatives (where the default declarative perspective is that of the speaker).

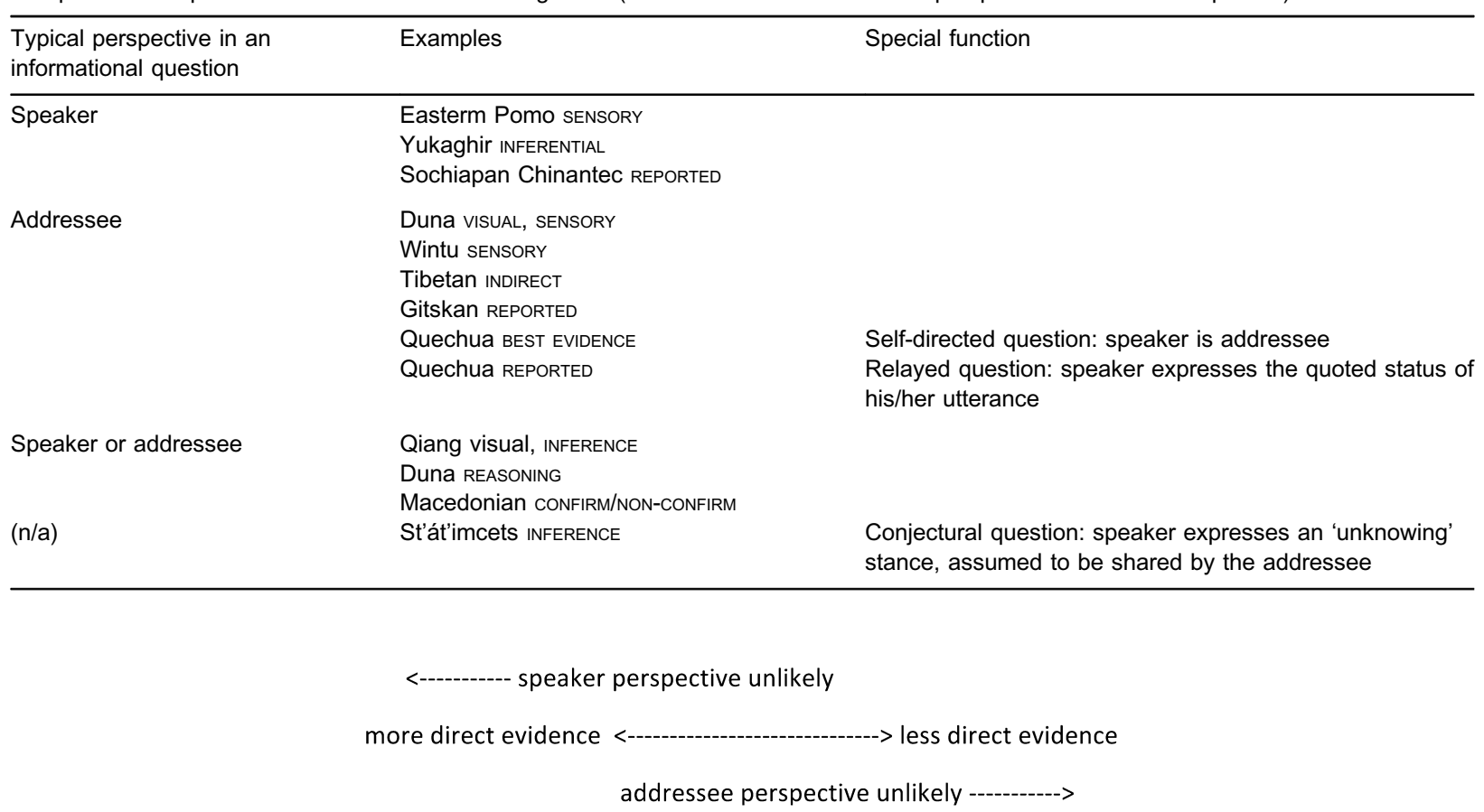

Fig. 1. Hypothesised relationship between evidential type and perspective in interrogatives.

The likelihood that speaker perspective will be used in questions may interact with positions on the hierarchy. For example, while we see report, inference, and non-visual sensory evidential markers that show speaker perspective in interrogatives (section 3.1), we have not found clear examples where a specifically participatory and/or visual evidential behaves in this way. (Although, we note that 'direct evidence' Eastern Pomo interrogatives presented by McLendon (2003:15) are ambiguous between speaker and addressee perspective.) A feasible hypothesis is that such examples are unusual because we are less likely to need to ask questions about events that we see or participate in. In other words, we are less likely to find interrogative evidentials that express speaker perspective for those evidential categories that are higher on a generalised evidential hierarchy.

As a partial corollary to this prediction, information source types that are lower on the hierarchy may be less likely to express addressee perspective. ${ }^{12} \mathrm{~A}$ range of different evidential categories in different languages (e.g. visual, non-visual sensory, inferred, reported, direct, indirect) are attested as expressing addressee perspective in interrogatives. However, evidentials with inferential or indirect meanings may be especially likely to 'opt out' of flipping to addressee perspective, for example maintaining speaker perspective, and/or expressing 'wondering' or otherwise rhetorical meanings when used in an interrogative clause (section 3.4). Any such tendency could have its origin in both informational dynamics (why ask a question of someone whom you do not expect to have preferred evidence?) and interactional appropriateness (how much is it polite to assume about addressee knowledge?).

The hypothesised relation between an evidential's position on a generalised hierarchy, and its likelihood of maintaining speaker perspective is represented in Fig. 1. According to this hypothesis, we will not find a language where a more direct evidential shows speaker perspective in questions, but a less direct evidential flips to addressee perspective; and indeed, we have not as yet found any such language. However, we note that it is problematic to generalise about the place of reported markers under the scenario expressed in Fig. 1. A more important issue than directness or indirectness of evidence may be whether the reported marker also functions as a quotative (section 3.4.3). If it does, we may expect that reportative interrogatives can (or even must) be interpreted as relayed questions, so that the issue of perspective is no longer relevant in the same way.

\footnotetext{
12 We say partial corollary because there is not a simple binary choice between speaker or addressee perspective. A morpheme can also express, for example, joint perspective, etc. Thus, unlikelihood of speaker perspective does not entail likelihood of addressee perspective, and vice versa.
} 
A related area of study in relation to perspective in interrogative structures is mirative markers (see Aikhenvald, 2012; DeLancey, 1997; Hill, 2012; Lazard, 1999 concerning relationships between evidentiality and mirativity). It may be more common for miratives in interrogatives to express speaker perspective, rather than (or as well as) addressee perspective. For example, according to Friedman (2003:202), the Albanian admirative expresses speaker surprise in both declaratives and interrogatives (see also Olbertz, 2009 concerning Ecuadorian Highland Spanish). As with the apparently scarce use of direct evidentials with speaker perspective in questions, the expression of mirativity in interrogatives may be conditioned by the informational and pragmatic dynamics of the speech setting. That is, a flip to addressee perspective is not predicted in this case: firstly, a speaker is unlikely to ask for information from someone who s/he simultaneously expects to be surprised about that information; and secondly, it may be presuming too much to assert the addressee's attitude in this way (however, see de Reuse, 2003:88-89 for a possible counter example in Athabaskan, and Hengeveld and Olbertz (2012:492) concerning addressee-centred mirativity in rhetorical questions).

\section{Person restrictions, perspective, and egophoric marking}

In the preceding discussion, we suggested that direct knowledge evidentials may be especially compatible with a switch to addressee perspective in interrogatives, as an assumption that our interlocuter has direct knowledge provides good grounds for asking him or her a question. It seems to 'make sense' that we would treat our own direct knowledge as grounds for assertion (i.e., expressing speaker perspective) but treat the direct knowledge of others as grounds for inquiry. We turn now to a grammatical phenomenon that concerns tracking the direct knowledge of interlocuters across different speech act types: egophoricity. Egophoricity is canonically defined by certain scholars as a pattern of morphological marking in which speaker subjects in statements are marked the same way as addressee subjects in questions (see, e.g., Curnow, 2002a), although this definition is rarely sufficient to account for the complexities present in individual languages (see, e.g., Tournadre, 2008). ${ }^{13}$ While the evidential literature has focused on 'kinds of knowing', an exceptionally strong interaction with the category of person has motivated the literature on egophoricity to focus on 'who knows'.

We begin our examination of egophoricity with background discussion of person-sensitive restrictions on evidential use (section 4.1) before turning to perspective shifting properties of egophoric systems and their relationship to evidentiality (section 4.2). Throughout this discussion we use the term 'subject' following source authors' terminology and in a fairly broad sense to refer to a privileged argument role that usually equates to the single argument (S) of a monovalent verb and the more agent-like argument (A) of a multivalent verb. More precise syntactic, semantic and discourse-related properties will differ across languages (for example, for inverse agreement systems relative animacy may be more important than agency for assigning subjecthood).

\subsection{Person restrictions in evidential marking}

Evidentials in statements often have strong biases regarding particular subject person categories, for example, an evidential may be frequent with third person subjects, but very scarce with first person subjects (see Curnow, 2002b; Aikhenvald, 2004a). For many languages, there is currently little information concerning how these restrictions and effects operate in interrogative clauses. However, in at least some languages one consequence of perspective shift is that features of use that centre around the speaker in declaratives transfer (at least in part) to the addressee in interrogatives.

This is the case in Duna, where all evidential markers are dispreferred for speaker subjects in declaratives. In Duna, actions that one performs oneself are not usually described through reference to one's external perception (cf. the oddness of something like I saw myself reading in English). For example, Duna speakers judge constructed declarative clauses that have both visual marking and a first person subject pronoun (33a) as incorrect and unsayable (although such combinations can occur in natural speech in particular circumstances, see San Roque, 2008). Evidentials can be used unproblematically with a second person subject (33b) and with third person subjects (see, e.g., 16 and 17b).
a) ?*no hutia
1sG come.PFV.VIS
I came (I saw)
b) ko hutia
2sG come.PFV.VIS
'You came (I saw).'

\footnotetext{
${ }^{13}$ Egophoricity is known by a number of labels, including 'conjunct/disjunct' (Hale, 1980 and others), 'assertor involvement' (Creissels, 2008), 'congruent/non-congruent' (Dickinson, 2000), and 'locuter/non-locuter' (earlier works of Curnow, e.g., 1997), while the term 'egophoric' was first established in this particular context by Tournadre (e.g., 1996). The proliferation of terms indicates the lack of general agreement as to its function and its status as a typological category sui generis.
} 
Core argument NPs are not obligatory in Duna, and the dispreference for evidentials with speaker subjects can affect the interpretation of clausal argument structure. For example, for the constructed declarative clause (34), speakers interpreted the first person pronoun as an object argument, and assumed there was an elided third person subject. Thus, evidentials can work as a proxy for (non-first) subject person marking. ${ }^{14}$

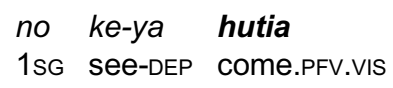

In interrogative clauses, the restriction applies to second person rather than first person, as the event is now presented in relation to the addressee's (assumed) perceptual experience. Evidentially marked interrogative clauses which have a second person subject are judged unacceptable (35). In transitive clauses an overt second person pronoun can be interpreted as an object, with an elided third person subject (36). (Interrogative clauses that combine first person and evidential marking are acceptable, but constructed examples are usually interpreted as having some kind of rhetorical value owing to the relative rarity of asking a first person question.)

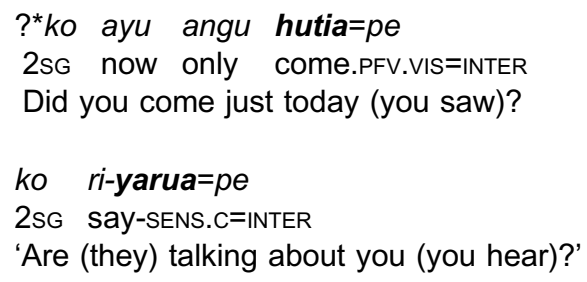

In sum, Duna evidential semantics and typical perspective interpretations combine to create a negative prediction concerning subject identity. In Duna, declaratives marked with evidentials are unlikely to have a speaker subject, and interrogatives marked with evidentials are unlikely to have an addressee subject.

\subsection{Egophoric marking}

\subsubsection{The basic pattern}

In contrast to the Duna situation, the positive grouping of declarative speaker subjects and interrogative addressee subjects is a central feature of languages with so-called egophoric ('conjunct/disjunct') marking systems. Such languages employ special 'egophoric' verb forms (generally involving special verbal inflectional morphology or dedicated auxiliaries) where the subject (and/or another privileged argument role) is first person in declaratives or second person in interrogatives. ${ }^{15}$ Examples (37-42) from Cha'palaa (a Barbacoan language of Ecuador) illustrate this pattern. In statements, the EGO marker -yu occurs where the subject of the sentence is the speaker, while the NON-EGO marker -we occurs wherever the subject is the addressee or a non-speech act participant (third person). Personal pronouns are optional, but can be used for disambiguation if necessary.

$$
\begin{aligned}
& \text { (i-ya) pipe-yu } \\
& \text { 1-TOP bathe-EGO } \\
& \text { I bathed. } \\
& \text { (ñu/ya) pipe-we } \\
& 2 / 3 \text { bathe-N.EGO } \\
& \text { You/she bathed. }
\end{aligned}
$$

In questions, the EGO marker $-y u$ associates with addressee subjects (39-40), in opposition to other morphemes that associate with third-person (41) and first-person (42) subjects (see Floyd, in press for further details and discussion).

\footnotetext{
$\overline{14}$ Duna also has 'optional' ergative marking on subject pronouns so the fact that the pronoun in (34) is not ergative supports its interpretation as an object. However, ergative marking is conditioned by animacy and information structure as well as syntactic role, and the pronoun no '1sG' would be a viable subject argument if the evidential were not also present.

${ }^{15}$ Egophoric markers also typically associate with speaker subjects in embedded speech reports, but we do not discuss this attribute here.
} 
(39) (ñu-ya) pipe-yu

2-FOC bathe-EGO

'Did you bathe?'

(40) Ti-ee ke-yu (ñu)

what-FOC do-EGO 2

'What did you do?'

(ya-a) pipe-n

3-FOC bathe-N.EGO.Q

'Did she bathe?'

(i-ya) pipe-wa

1-FOC bathe-SPKR.Q

'Did I bathe?'

The basic egophoric pattern can be observed in unrelated languages in places as diverse as the Himalayas, the Caucasus, the Andes, and Highlands New Guinea. However, it is only recently that these dots have been connected to try and develop a cross-linguistically coherent account of this distinctive morphological distribution, for example as personmarking, evidentiality, or something else altogether (see, e.g., Creissels, 2008; Floyd, in press). We briefly review these alternative viewpoints before looking at how egophoric interrogatives compare to evidential interrogatives.

\subsubsection{Egophoric markers and the category of person}

Typological literature concerning the category of person has proposed that the egophoric pattern is a kind of person marking (e.g., Bickel and Nichols, 2007:223; Cysouw, 2003; Dixon, 2010:222-223; although see also Bickel, 2008 for a subtly different view). Unlike person markers as they are usually understood, egophoric markers do not clearly index a single speech act role such as speaker or addressee (nor a predictable conflation of such roles, e.g., as in non-first agreement systems). However, it has been suggested that they show 'agreement' for the alternative, epistemically based role of 'epistemic authority', loosely defined as the supplier or source of information. Typically, this will be the speaker in a statement and the addressee in a question (see, e.g., Hargreaves, 1991, 2005; Creissels, 2008; Evans, 1996; Post, 2013 and Wechsler, in press for richer discussions of this proposed role in regard to specific languages).

Under a person-marking account, egophoric markers flag the coincidence of the epistemic authority and an argument role (usually, although not always, the subject) in a given speech act (Bickel and Nichols, 2007). Thus, what examples (37) and (39-40) have in common is that the epistemic authority is also the subject, and this is what triggers egophoric marking. This analysis can describe much of the cross-linguistic data, but has trouble accounting for additional semantic and pragmatic factors that are important in conditioning egophoric marking in individual languages-for example, in Kathmandu Newar, egophoric marking is appropriate for volitional subjects but cannot be used for non-volitional activities (Hale, 1980), while in Mangghuer (Mongolic), co-identity of the epistemic authority and an external possessor can also trigger egophoric marking (Fried, in press). In fact, most (if not all) languages that have been identified as egophoric have quirks and caveats that confound a straightforward agreement analysis. Furthermore, unlike the roles of speaker and addressee, there is no reliable way to identify the epistemic authority except in relation to the specific content and sequential context of an utterance (e.g., as a question, statement, etc.), and this considerably weakens an analysis of egophoric markers as primarily indexical.

\subsubsection{Egophoric markers and personal knowledge}

An alternative approach is to view egophoric forms as marking a special kind of knowledge, that is, direct personal experience of an event. Like evidential markers that shift perspective, egophoric markers reflect the speaker's knowledge of the narrated situation in a statement, and flip to express the addressee's (presumed) knowledge in an interrogative. As a subject will normally have good grounds to assert direct personal knowledge of an event, it naturally follows that declaratives with a first person subject usually take egophoric marking (I assert my own actions with reference to my relationship of personal knowledge), as do interrogatives with a second person subject (I question your actions with reference to your relationship of personal knowledge). The distribution of egophoric markers is thus the inverse of visual evidentials in Duna, where a speaker cannot appropriately assert their own actions with reference to their own visual experience (etc.), nor question the actions of an addressee in this way.

Several scholars have thus proposed that egophoric markers are a special evidential category of 'ego' evidentiality, specifying that one knows about an event or situation from personal experience or agentive participation (DeLancey, 2001:372; Garrett, 2001:102; Tournadre, 2008:284). While an 'information source' interpretation has been explicitly 
rejected by some writers (e.g., Aikhenvald, 2004a:127; Hongladarom, 2007; Thurgood, 1986), the view that egophoricity is a type of evidentiality is especially compelling for languages where EGo markers contrast paradigmatically with 'classic' evidential morphemes such as visual and other sensory markers (e.g., as in Oksapmin (Loughnane, 2009), Lhasa Tibetan (Garrett, 2001), Foe (Rule, 1977) and Guambiano (Norcliffe, in press). However, for some egophoric languages there is less motivation for an evidential interpretation, as information source is not (otherwise) grammaticalised. In such cases, it may be more appropriate to consider egophoric markers as expressions of 'primary knowerhood' that make a claim of intimate involvement with an event, but are not primarily concerned with indicating contrastive values of information source.

\subsubsection{Egophoric markers and interrogativity}

As we saw in section 2.5 , there is variation cross-linguistically as to whether evidentials can occur in interrogative contexts. The suitability of posing this same question for egophoric markers depends on one's analytic approach to the phenomenon. On the analysis that egophoric markers are a type of agreement with an epistemically based role of 'epistemic authority' which subsumes the speaker in declaratives and the addressee in interrogatives (section 4.2.2), egophoric marking, must, by definition, occur in (addressee subject) interrogatives (i.e., if it does not, then it is not egophoric marking). On the alternative analysis, that egophoric marking is a subtype of evidentiality (section 4.2.3), it is a logical possibility that, like any other type of evidential, markers of personal knowledge might, in some languages, be restricted to declarative contexts only (see also Gawne, 2013). ${ }^{16}$

Guambiano (Barbacoan) represents an interesting case of how egophoric morphology can, like the markers discussed in section 2, exhibit restrictions based on sentence type. In declarative sentences, the inflection -ar occurs wherever the subject is first person (i.e., when the speaker is making claims about his or her own actions) (43). - Ar stands in a paradigmatic relationship with a set of evidential morphemes, including -an, a 'best evidence' marker (44) (in the sense of Faller, 2002a), -tre, a visual evidential (45), and -shi, a marker of non-visual sensory evidence (46). Significantly, -ar parallels the behaviour of these other evidential categories in being restricted to declarative contexts. -Ar therefore does not exhibit the 'interrogative flip' so characteristic of ego markers in other languages. Nevertheless, interrogatives in Guambiano do appear to exhibit a sensitivity to egophoric contrasts. In interrogatives, a special question particle $k u$ is used where the addressee is being asked about his or her own actions (47). ${ }^{17} \mathrm{Ku}$ only occurs with second person questions; questions about the actions of non-addressees (first or third person) are unmarked (48).

(na) pentana-wan kur-ar

1sG window-ACC open-EGo

'I opened the window.'

(ni) kur-an

2/3.PROX open-BEst.eV

'He/she/you opened it.'

chucha amtru-tre!

possum come-vis.ev

'A possum is coming!'

(46)

$$
\begin{aligned}
& \text { pil-pe tirchik pasri-shi } \\
& \text { moon-TOP bright hang-SENS.EV } \\
& \text { 'The moon is bright' }
\end{aligned}
$$

$$
\begin{aligned}
& \text { chap trukul-wan pillma ku? } \\
& \text { already teeth-ACC wash EGO.INTER } \\
& \text { 'Did you clean your teeth already?' }
\end{aligned}
$$

\footnotetext{
${ }^{16}$ The 'performative' evidential of Kashaya (Pomo) (Oswalt, 1986), and the 'personal agency' evidential of Eastern Pomo (Mithun, 1999) may well fit into this category, though it is not clear from published data whether the markers in these languages are strictly limited to declaratives. Oswalt, for example, describes Kashaya's performative evidential as indicating that the speaker knows of what he speaks because he is performing the action himself or has just performed it' (Oswalt, 1986:34). Other possible candidates for this kind of system could be intentive modality markers that are restricted to first person in declaratives, with no corresponding form or meaning contrast available in interrogatives, as is apparently the case in Foe (Rule, 1977).

${ }^{17} \mathrm{Ku}$ alternates with (at least) one other interrogative particle, titru, which is also restricted to interrogative contexts in which the subject is the addressee. It has not yet been established what determines the choice between the two particles (they are interchangeable in both polar and in content questions).
} 
na/ni sruk kutsa?

1.sG/2/3PROX stone throw

'Did I/he/she throw the stone?'

Guambiano therefore appears to preserve a functional contrast between ego and non-ego categories in both declaratives and in interrogatives, albeit via distinct morphological means. ${ }^{18}$ This presents an interesting parallel with evidential marking in languages such as Tariana (section 2.4), which have distinct declarative and interrogative forms.

In relation to perspective in interrogatives (section 3), egophoric markers appear to obligatorily shift from speaker to addressee perspective. As already mentioned, this accords well with the proposal that markers that indicate direct knowledge are highly likely to undergo perspective switch. Indeed, it is quite hard to imagine using an ego marker with speaker perspective in a question that also has a second person subject (e.g., did you wash-EGo the dishes?). This would require a context in which a speaker ostensibly asks for information about an event in which the addressee acted as an agent (as signalled by an interrogative structure with a second person subject), while simultaneously claiming participatory knowledge of that event (as signalled by the use of an egophoric marker expressing speaker perspective). ${ }^{19}$

\section{Summary and concluding remarks}

In this paper we have sketched several formal, semantic, and pragmatic components of cross-linguistic variation associated with the expression of evidentials in interrogatives. In doing so, we have considered (1) the possibilities for marking evidentiality across different sentence types, (2) the different meanings that evidentials have when used with different sentence types, particularly in terms of whether the perspective stays anchored to the speaker or shifts to the addressee, and (3) the relationship of evidential systems to egophoric systems, which feature a similar kind of perspective shift.

Given the heterogeneity of evidential marking, evidential interrogative behaviour is better described in terms of individual morphemes rather than evidential 'systems' as a whole, as both how an evidential value is formally marked and a marker's particular semantics help structure its possibilities of use across different sentence types. In terms of the cooccurrence of evidential and interrogative structures, the range of attested possibilities includes a formally 'symmetric' distribution where all evidential markers that occur in declaratives can also occur in interrogatives; the presence of formal restrictions on some evidentials and/or some question types; or a lack of any evidential contrasts in interrogatives. A final formal asymmetry attested in several unrelated languages is a 'split' system, with distinct interrogative evidential morphemes or constructions.

Complete exclusion of all evidential markers from both polar and content interrogatives is rare cross-linguistically, but partial exclusions appear to be reasonably common. In many cases this reflects the fact that the evidential 'system' is a disparate grouping of morphemes rather than a single paradigm, with different formal constraints applying across the group. A reason for partial or complete exclusion of evidential interrogatives noted in several languages is that interrogative and evidential morphology occur in the same slot in the clause, showing a close relationship between evidentiality and sentential mood.

One of the most intriguing and important features of interrogative evidentials is how they behave in terms of perspective. Among evidential markers that typically take speaker perspective in declarative clauses, we have discussed three possibilities: interrogative evidentials also take speaker perspective; interrogative evidentials take addressee perspective; or perspective is fluid, and the evidential can be interpreted as reflecting either speaker or addressee perspective. Switching to addressee perspective in questions is probably the most common practice overall, and is the only currently attested possibility for split systems. For some languages, evidential interrogatives have special functions, for example as self-directed questions or expressions of 'wondering', rather than as information-seeking questions, and these entail their own perspectival interpretations. Apart from the examples discussed, it is clear that there is a range of

\footnotetext{
${ }^{18}$ Dime (Omotic, Ethiopia) appears to possess a system similar to Guambiano's. It is described as having a first/non first system of subject person marking which is restricted to affirmative contexts, as well as special marking for polar interrogatives with second person subjects (Seyoum, 2008).

19 While specialised sarcastic or rhetorical uses might work (e.g., saying something like, so you washed the dishes, did you? when you were supposed to wash the dishes but I was the one who actually washed them), genuine information-seeking questions with these features seem somewhat less likely. Some potential scenarios might be where the speaker and addressee have acted together (e.g., did you and I wash the dishes yesterday?), where the speaker takes responsibility for the addressee's (involuntary) action or state (e.g., do you feel grateful that I washed the dishes?) or, for languages where egophoric markers are triggered by non-subject arguments, clauses where the addressee is an agent but the speaker is an object argument or external possessor, etc.
} 
other possible perspective relationships that can be expressed by evidential markers, and this is a key area for further investigation.

There is some indication that information source categories that are 'high' on a generalised evidential hierarchy (participatory > visual, etc.) are less likely to show speaker perspective in interrogatives, and that information source types that are low on such a hierarchy are less likely to be used with addressee perspective. This tendency has a viable pragmatic explanation: the favoured addressee of a question is likely to be someone with direct knowledge of the queried event or situation. This 'favouritism' is further observable in egophoric systems, where an addressee who likely has direct knowledge (e.g., is a subject or other core argument) is morphologically 'privileged' in the same way as a speaker with direct knowledge. Both evidential and egophoric systems are sensitive to the role of 'epistemic authority' (typically, the speaker in a statement and the addressee in a question); egophoric markers are often treated, in effect, as crossreferencing this role. This emphasises how knowledge-related morphology establishes a relationship between a speech act participant and the narrated event or situation, although this may not be 'deictic' in the usual sense.

A more comprehensive cross-linguistic survey will need to examine whether there are tendencies as to (i) whether particular question types are more likely to be compatible with evidential markers, (ii) how the morphosyntactic features of an evidential may condition its occurrence in questions, (iii) whether particular information source categories are more likely than others to be prohibited (or dispreferred) in interrogatives, and (iv) the extent to which these tendencies interact with each other and with issues of perspective.

We have argued that perspective is especially central to accounting for evidential semantics in context, and for understanding the social-cognitive implications of evidential and egophoric markers. For many languages, interrogative evidentials highlight the fact that an entirely speaker-centric view is not adequate for explaining the meanings and uses of evidential forms. Further collection and analysis of multi-party interactive data is likely to be especially revealing in terms of how perspective relationships are established and exploited cross-linguistically. Such data may help us to understand how information source and related semantic domains are treated not as epistemic abstractions, but as lived and spoken experience.

Attending to the potential for varied and multiple perspectives in the analyses of evidentials and related systems, in contrast with more exclusively speaker-centric accounts, is thus one step towards building on our present understanding of knowledge-based grammar in the speech situation. Far from being restricted to systems of bound morphology, we note that the perspectivising nature of evidential and egophoric categories in relation to speaker and addressee is common to a range of knowledge-based phenomena in language, for example, Japanese 'private predicates' (Evans, 1996; Nariyama, 2003), modal markers (Lehmann, 2011), or epistemic biases that structure conversation (e.g., Labov and Fanshell, 1977; Heritage, 2012; Hayano, 2013). These diverse grammatical, lexical and conversational systems reflect our extraordinary sensitivity to the way knowledge is distributed and manipulated in our interactions with others.

\section{Acknowledgements}

We gratefully acknowledge our main funding support from the Max Planck Institute for Psycholinguistics (Language and Cognition Department) and secondarily from the European Research Council (Project: Human Sociality and Systems of Language Use, Starting Grant no. 240853). San Roque's research was additionally funded by the Swedish Research Council (Project: Complex Perspective in Epistemic Assessment) and is partly based on fieldwork funded by the Australian Research Council (Project: Language and Social Cognition). Thanks to the Wenner-Gren foundation for sponsoring an earlier workshop relevant to this topic, to four anonymous reviewers, and to Jeffrey Muehlbauer and Nathan Hill for their helpful criticisms and comments on earlier drafts. Finally and fundamentally, thank you to: the community of Tsejpi (Cha'palaa); the Rewapi and Rale communities, especially Petros Kilapa (Duna); Luis Enrique Tunubala Ussa and Juan Calambas Muelas (Guambiano); the Lema family of Peguche (Quechua); and Randy LaPolla and Chenglong Huang (Qiang) for provision and discussion of data. Any errors are our own responsibility.

\section{References}

Aikhenvald, A.Y., 2003. A Grammar of Tariana from Northwest Amazonia. Cambridge University Press, Cambridge.

Aikhenvald, A.Y., 2004a. Evidentiality. Oxford University Press, Oxford.

Aikhenvald, A.Y., 2004b. Evidentiality: problems and challenges. In: van Sterkenburg, P. (Ed.), Linguistics Today - Facing A Greater Challenge.

John Benjamins, Amsterdam/Philadelphia, pp. 1-29.

Aikhenvald, A.Y., 2012. The essence of mirativity. Linguist. Typol. 16, 435-485.

Aikhenvald, A.Y., Dixon, R.M.W. (Eds.), 2003. Studies in Evidentiality. John Benjamins, Amsterdam/Philadelphia.

Anderson, L.B., 1986. Evidentials, paths of change, and mental maps: typologically regular asymmetries. In: Chafe, W., Nichols, J. (Eds.),

Evidentiality: The Linguistic Coding of Epistemology. Ablex, Norwood, NJ, pp. 273-312.

Arakaki, T., 2013. Evidentials in Ryukyuan: The Shuri Variety of Luchuan. Brill, Leiden.

Barnes, J., 1984. Evidentials in the Tuyuca verb. Int. J. Am. Linguist. 50, 255-271. 
Barr, D.J., Keysar, B., 2007. Perspective taking and the coordination of meaning in language use. In: Traxler, M.J., Gernsbacher, M.A. (Eds.), Handbook of Psycholinguistics. 2nd ed. Academic Press, San Diego, pp. 901-938.

Bendix, E.H., 1993. The grammaticalization of responsibility and evidence: interactional manipulation of evidential categories in Newari. In: Hill, J. H., Irvine, J.T. (Eds.), Responsibility and Evidence in Oral Discourse. Cambridge University Press, Cambridge, pp. $226-247$.

Bickel, B., 2008. Verb agreement and epistemic marking: a typological journey from the Himalayas to the Caucasus. In: Huber, B., Volkart, M., Widmer, P. (Eds.), Chomolangma, Demawend und Kasbek: Festschrift für Roland Bielmeier zu seinem 65 Geburtstag. International Institute for Tibetan and Buddhist Studies, Halle, pp. 1-14.

Bickel, B., Nichols, J., 2007. Inflectional morphology. In: Shopen, T. (Ed.), Language Typology and Syntactic Description. revised 2nd ed. Cambridge University Press, Cambridge, pp. 169-240.

Boye, K., 2012. Epistemic Meaning: A Cross-Linguistic and Functional-Cognitive Study. de Gruyter Mouton, Berlin.

Brugman, C., Macaulay, M., 2010. Characterizing Evidentiality (Poster presentation). LSA, Boston.

Chafe, W.L., 1986. Evidentiality in English conversation and academic writing. In: Chafe, W.L., Nichols, J. (Eds.), Evidentiality: The Linguistic Coding of Epistemology. Ablex, Norwood, NJ, pp. 261-272.

Chirikba, V., 2003. Evidential category and evidential strategy in Abkhaz. In: Aikhenvald, A.Y., Dixon, R.M.W. (Eds.), Studies in Evidentiality. John Benjamins, Amsterdam, pp. 243-272.

Chisholm, W.S. (Ed.), 1984. Interrogativity: A Colloquium on the Grammar, Typology and Pragmatics of Questions in Seven Diverse Languages. John Benjamins, Amsterdam/Philadelphia.

Coler, M., 2014. A Grammar of Muylaq' Aymara. Brill, Leiden.

Creissels, D., 2008. Person variations in Akhvakh verb morphology: functional motivation and origin of an uncommon pattern. Sprachtypol. Univers. 61 (4), 309-325.

Curnow, T.J., 1997. A Grammar of Awa Pit (Cuaiquer): An Indigenous Language of South-Western Colombia (PhD dissertation). Australian National University.

Curnow, T.J., 2002a. Conjunct/disjunct marking in Awa Pit. Linguistics 40 (3), 611-627.

Curnow, T.J., 2002b. Types of interaction between evidentials and first-person subjects. Anthropol. Linguist. 44, $178-196$.

Cysouw, M., 2003. The Paradigmatic Structure of Person Marking. Oxford University Press, Oxford.

Dancygier, B., Sweetser, E. (Eds.), 2012. Viewpoint in Language. Cambridge University Press, Cambridge.

Davis, C., Potts, C., Speas, M., 2007. The pragmatic values of evidential sentences. In: Friedman, T., Gibson, M. (Eds.), SALT XVII. Cornell University, Ithaca, NY, pp. 71-88.

De Haan, F., 2005. Encoding speaker perspective: evidentials. In: Frajzyngier, Z., Roods, D. (Eds.), Linguistic Diversity and Language Theories. John Benjamins, Amsterdam/Philadelphia.

de Haan, F., 2013. Coding of evidentiality. In: Dryer, M.S., Haspelmath, M. (Eds.), The World Atlas of Language Structures Online. Max Planck Institute for Evolutionary Anthropology, Leipzig. http://wals.info/chapter/78

de Reuse, W.J., 2003. Evidentiality in Western Apache (Athabaskan). In: Aikhenvald, A.Y., Dixon, R.M.W. (Eds.), Studies in Evidentiality. John Benjamins, Philadelphia, pp. 79-100.

de Ruiter, J.P. (Ed.), 2012. Questions: Formal, Functional, and Interactive Perspectives. Cambridge University Press, Cambridge.

de Schepper, K., de Hoop, H., 2012. Construction-dependent person hierarchies. In: Abraham, W., Leiss, E. (Eds.), Modality and Theory of Mind Elements Across Languages. De Gruyter, Berlin/Boston, pp. 383-404.

DeLancey, S., 1997. Mirativity: the grammatical marking of unexpected information. Linguist. Typol. 1 (1), 33-52.

DeLancey, S., 2001. The mirative and evidentiality. J. Pragmat. 33, 369-382.

Dickinson, C., 2000. Mirativity in Tsafiki. Stud. Lang. 24 (2), 379-421.

Dixon, R.M.W., 2003. Evidentiality in Jarawara. In: Aikhenvald, A.Y., Dixon, R.M.W. (Eds.), Studies in Evidentiality. John Benjamins, Amsterdam/ Philadelphia, pp. 165-187.

Dixon, R.M.W., 2004. The Jarawara Language of Southern Amazonia. Oxford University Press, Oxford.

Dixon, R.M.W., 2010. Basic Linguistic Theory. Oxford University Press, Oxford.

Du Bois, J.W., 2007. The stance triangle. In: Engelbretson, R. (Ed.), Stancetaking in Discourse. John Benjamins, Amsterdam/Philadelphia, pp. 139-182.

Enfield, N.J., 2003. Demonstratives in space and interaction: data from Lao speakers and implications for semantic analysis. Language 79 , 82-117.

Enfield, N.J., Levinson, S.C. (Eds.), 2006. Roots of Human Sociality: Culture, Cognition and Interaction. Berg, Oxford.

Epps, P., 2008. A Grammar of Hup. Mouton de Gruyter, Berlin.

Evans, N., 1996. Grammaticizing the Knower: Towards A Partial Typology of Person Effects on Predicates. Plenary. Third Australian Linguistics Institute, The Australian National University.

Evans, N., 2007. View with a view: towards a typology of multiple perspective. Berkeley Linguist. Soc. 31, 93-120.

Evans, N., 2010. Dying Words: Endangered Languages and What They Have to Tell Us. Wiley-Blackwell, Oxford.

Faller, M., 2002a. Semantics and Pragmatics of Evidentials in Cuzco Quechua (PhD dissertation). Stanford University.

Faller, M., 2002b. Remarks on evidential hierarchies. In: Beaver, D., Casillas Martínez, L.D., Clark, B.Z., Kaufmann, S. (Eds.), The Construction of Meaning. CSLI, Stanford, CA, pp. 89-111.

Fleck, D., 2003. A Grammar of Matses (PhD dissertation). Rice University.

Floyd, S., 2005. The poetics of evidentiality in South American storytelling. In: Harper, L., Jany, C. (Eds.), Proceedings from the Eighth Workshop on American Indigenous Languages. University of California, Santa Barbara, Santa Barbara, CA, pp. 28-41.

Floyd, S., 2010. Discourse Forms and Social Categorization in Cha'palaa (PhD dissertation). University of Texas, Austin.

Floyd, S., 2011. Re-discovering the Quechua adjective. Linguist. Typol. 15, 25-63. http://dx.doi.org/10.1515/LITY.2011.003

Floyd, S., in press. Egophoricity and argument structure in Cha'palaa. In: Floyd, S., Norcliffe, E., San Roque, L. (Eds.), Egophoricity. John Benjamins, Amsterdam.

Foris, D.P., 1993. A Grammar of Sochiapan Chinantec (PhD dissertation). University of Auckland. 
Forker, D., 2014. The grammar of knowledge in Hinuq. In: Aikhenvald, A.Y., Dixon, R.M.W. (Eds.), The Grammar of Knowledge: A CrossLinguistic Typology. Oxford University Press, Oxford, pp. 52-68.

Fried, R.W., in press. Egophoricity in Mangghuer: insights from pragmatic uses of the subjective/objective distinction. In: Floyd, S., Norcliffe, E. San Roque, L. (Eds.), Egophoricity. John Benjamins, Amsterdam.

Friedman, V.A., 2003. Evidentiality in the Balkans with special attention to Macedonian and Albanian. In: Aikhenvald, A.Y., Dixon, R.M.W. (Eds.) Studies in Evidentiality. John Benjamins, Amsterdam/Philadelphia, pp. 189-218.

Friedman, V., 2004. The typology of Balkan evidentiality and areal linguistics. In: Tomić, O.M. (Ed.), Balkan Syntax and Semantics. John Benjamins, Amsterdam, pp. 101-134.

Garrett, E.J., 2001. Evidentiality and Assertion in Tibetan (PhD dissertation). University of California, Los Angeles.

Gawne, L., 2013. Lamjung Yolmo Copulas in Use: Evidentiality, Reported Speech and Questions (PhD dissertation). The University of Melbourne.

Grunow-Hårsta, K., 2007. Evidentiality and Mirativity in Magar. In: Aikhenvald, A., LaPolla, R.J. (Eds.), Linguistics of the Tibeto-Burman Area, 30 (2). pp. 151-194 (Special Issue).

Guldemann, T., 2008. Quotative Indexes in African Languages: A Synchronic and Diachronic Survey. Mouton de Gruyter, Berlin.

Hale, A., 1980. Person markers: finite conjunct and disjunct verb forms in Newari. In: Papers in South-East Asian Linguistics No. 7. Pacific Linguistics, Canberra, pp. 95-106.

Hanks, W., 1990. Referential Practice: Language and Lived Space Among the Maya. University of Chicago Press, Chicago.

Hanks, W., 2005. Explorations in the deictic field. Curr. Anthropol. 46, 191-220.

Hanks, W., 2012. Evidentiality in social interaction. Pragmat. Soc. 3 (2), 169-180.

Hardman, M.J., 1986. Data-source marking in the Jaqi languages. In: Chafe, W.L., Nichols, J. (Eds.), Evidentiality: The Linguistic Encoding of Epistemology. Ablex, Norwood, NJ, pp. 113-136.

Hardman, M.J., 2000. Jaqaru. Lincom Europa, Germany.

Hargreaves, D., 1991. The conceptual structure of intentional action: data from Kathmandu Newari. In: Proceedings of the Seventeenth Annual Meeting of the Berkeley Linguistics Society.

Hargreaves, D., 2005. Agency and intentional action in Kathmandu Newar. Himal. Linguist. 5, 1-48.

Harris, A.C., 1984. Georgian. In: Chisholm, W.S. (Ed.), Interrogativity: A Colloquium on the Grammar, Typology and Pragmatics of Questions in Seven Diverse Languages. John Benjamins, Amsterdam/Philadelphia, pp. 63-112.

Hayano, K., 2013. Territories of Knowledge in Japanese Conversation (PhD dissertation). Radboud University.

Hengeveld, K., Olbertz, H., 2012. Didn't you know? Mirativity does exist!. Linguist. Typol. 16 (3), 487-503.

Heritage, J., 2012. Epistemics in action: action formation and territories of knowledge. Res. Lang. Soc. Interact. 45, 1-29.

Hewitt, B.G., in collaboration with Z.K. Khiba, 1979. Abkhaz. North Holland Publishing Company, Amsterdam.

Hill, N.W., 2012. "Mirativity" does not exist: hdug in "Lhasa" Tibetan and other suspects. Linguist. Typol. 16 (3), 389-433.

Hill, N.W., 2013. Contextual semantics of 'Lhasa' Tibetan evidentials. SKASE J. Theor. Linguist. 10 (3), 47-54.

Hongladarom, K., 2007. Evidentiality in Rgyalthang Tibetan. In: Aikhenvald, A., LaPolla, R.J. (Eds.), Linguistics of the Tibeto-Burman Area, 30 (2). pp. 17-44 (Special Issue).

Idiatov, D., van der Auwera, J., 2008. From nominalizations to questions - evidence from Tucanoan. Jezikoslovje 9, 35-51.

Jacobsen, W.H., 1986. The heterogeneity of evidentials in Makah. In: Chafe, W.L., Nichols, J. (Eds.), Evidentiality: The Linguistic Encoding of Epistemology. Ablex, Norwood, NJ, pp. 3-28.

Jakobson, R., 1957. Shifters and Verbal Categories. Harvard University, Department of Slavic Languages and Literatures, Cambridge, MA Reprinted In: Waugh L.R., Monville-Burston M. (Eds.), 1990. On Language, 386-392. Cambridge, MA: Harvard University Press.

Jespersen, O., 1924. The Philosophy of Grammar. Allen and Unwin, London.

Johanson, L., 2000. Turkic indirectives. In: Johansen, L., Utas, B. (Eds.), Evidentials: Turkic, Iranian, and Neighbouring Languages. Mouton de Gruyter, Berlin/NewYork, pp. 61-87.

Johanson, L., 2003. Evidentiality in Turkic. In: Aikhenvald, A.Y., Dixon, R.M.W. (Eds.), Studies in Evidentiality. John Benjamins, Amsterdam/ Philadelphia, pp. 273-290.

Kamio, A., 1997. Territory of Information. John Benjamins, Amsterdam/Philadelphia.

Kaplan, D., 1989. Demonstratives. In: Almog, P., Wettstein, H. (Eds.), Themes from Kaplan. Oxford University Press, Oxford.

Kehayov, P., 2008. An areal-typological perspective to evidentiality: the cases of the Balkan and Baltic linguistic areas. In: Dissertationes Linguisticae Universitatis Tartuensis, p. 10.

Kockelman, P., 2004. Stance and subjectivity. J. Linguist. Anthropol. 14 (2), 127-150.

Kroeker, M., 2001. A descriptive grammar of Nambikuara. Int. J. Am. Linguist. 67, 1-87.

Labov, W., Fanshell, D., 1977. Therapeutic Discourse: Psychotherapy as Conversation. Academic Press, New York.

LaPolla, R.J., 2003a. In: Aikhenvald, A.Y., Dixon, R.M.W. (Eds.), Evidentiality in Qiang, pp. 63-78.

LaPolla, R.J., with C. Huang, 2003b. A Grammar of Qiang with Annotated Texts and Glossary. Mouton de Gruyter, Berlin.

Lasersohn, P., 2005. Context dependence, disagreement, and predicates of personal taste. Linguist. Philos. 28, 643-686.

Lawrence, M., 1987. Viewpoint in Oksapmin. Lang. Linguist. Melanesia 16, 54-70.

Lazard, G., 1999. Mirativity, evidentiality, mediativity, or other? Linguist. Typol. 3, 91-109.

Lehmann, C., 2011. Speech act participants in modality. http://www.christianlehmann.eu/publ/lehmann_modality.pdf

Levinson, S.C., 1983. Pragmatics. Cambridge University Press, Cambridge.

Levinson, S.C., 2004. Deixis. In: Horn, L. (Ed.), The Handbook of Pragmatics. Blackwell, Oxford, pp. 97-121.

Levinson, S.C., 2012. Interrogative intimations: on a possible social economics of interrogatives. In: de Ruiter, J.P. (Ed.), Questions: Formal, Functional, and Interactive Perspectives. Cambridge University Press, Cambridge, p. 1132.

Lim, D., 2011. Evidentials in interrogatives: a case study of Korean. In: Reich, I., et al. (Eds.), Proceedings of Sinn and Bedeutung, vol. 15. University Press, Saarbrücken, Germany, pp. 419-433.

Littell, P., Matthewson, L., Peterson, T., 2010. On the semantics of conjectural questions. In: Peterson, T., Sauerland, U. (Eds.), Evidence from Evidentials, University of British Columbia Working Papers in Linguistics, vol. 28. pp. 89-104.

Loughnane, R., 2009. A grammar of Oksapmin (PhD dissertation). University of Melbourne. http://repository.unimelb.edu.au/10187/4788. 
Lyons, J., 1982. Deixis and subjectivity: Loquor ergo sum? In: Jarvella, R.J., Klein, W. (Eds.), Speech, Place, and Action: Studies in Deixis and Related Topics. John Wiley, Chichester and New York, pp. 101-124.

Madden, B. (no date) [c.1960]. An introduction to Mendi grammar. Manuscript.

Malone, T., 1988. The origin and development of Tuyuca evidentials. Int. J. Am. Linguist. 54, 119-140.

Maslova, E., 2003. Evidentiality in Yukaghir. In: Aikhenvald, A.Y., Dixon, R.M.W. (Eds.), Studies in Evidentiality. John Benjamins, Amsterdam/ Philadelphia, pp. 219-235.

Matthewson, L., Davis, H., Rullmann, H., 2007. Evidentials as epistemic modals: evidence from St'át'imcets. Linguist. Var. Yearb. 7, $201-254$.

McCready, E., 2007. Context shifting in questions and elsewhere. In: Puig-Waldmuller, E. (Ed.), Proceedings of Sinn und Bedeutung, vol. 11. Universitat Pompeu Fabra, Barcelona, pp. 433-447.

McLendon, S., 2003. Evidentials in Eastern Pomo with a comparative survey of the category in other Pomoan languages. In: Aikhenvald, A.Y., Dixon, R.M.W. (Eds.), Studies in Evidentiality. John Benjamins, Amsterdam/Philadelphia, pp. 101-129.

Michael, L., 2008. Nanti Evidential Practice: Language, Knowledge, and Social Action in an Amazonian Society (PhD dissertation). University of Texas at Austin.

Miestamo, M., 2011. Polar interrogatives in Uralic languages. Linguist. Ural. 47, 1-21.

Mithun, M., 1999. The Languages of Native North America. Cambridge University Press, Cambridge.

Mladenov, M., 1969. Govorăt na Novo Selo Vidinsko (The dialect of Novo Selo in the Vidin region). BAN, Sofia.

Mühlbauer, J., 2008. kâ-yôskâtahk ôma nêhiyawêwin: The Representation of Intentionality in Plains Cree (PhD dissertation). The University of British Columbia.

Murray, S., 2010. Evidentials and questions in Cheyenne. In: Lima, S. (Ed.), Proceedings of Semantics of Under-Represented Languages in the Americas, 5.

Mushin, I., 2001. Evidentiality and Epistemological Stance: Narrative Retelling. John Benjamins, Amsterdam.

Nariyama, S., 2003. Ellipsis and Reference Tracking in Japanese. John Benjamins, Amsterdam/Philadelphia.

Norcliffe, E., in press. Egophoricity and evidentiality in Guambiano. In: Floyd, S., Norcliffe, E., San Roque, L. (Eds.), Egophoricity. John Benjamins, Amsterdam.

Nuckolls, J., Michael, L. (Eds.), 2012. Evidentiality in Interaction: Special Issue of Pragmatics and Society, 3 (2).

Olbertz, H., 2009. Mirativity and exclamatives in functional discourse grammar. In: Keizer, E., Wanders, G. (Eds.), The London Papers I Web Papers in Functional Discourse Grammar. Functional Grammar Foundation, Amsterdam, pp. 66-82. http://dare.uva.nldocument/162366

Oswalt, R.L., 1986. In: Chafe, Nichols, (Eds.), The Evidential System of Kashaya, pp. 29-45.

Post, M., 2013. Person-sensitive TAME marking in Galo: historical origins and functional motivation. In: Thornes, T., Andvik, E., Hyslop, G., Jansen, J. (Eds.), Functional and Historical Approaches to Explanation: A Festscrhrift for Scott DeLancey. John Benjamins, Amsterdam.

Quirk, R., Greenbaum, S., Leech, G., Svartvik, J., 1989. A Comprehensive Grammar of the English Language. Longman, London.

Rubio-Fernández, P., 2008. On the automaticity of egocentricity: a review of the egocentric anchoring and adjustment model of perspective taking. In: University College London Working Papers in Linguistics (UCLWPL) 20.

Rule, W.M., 1977. A Comparative Study of the Foe, Huli, and Pole Languages of Papua New Guinea. University of Sydney, Sydney.

Sadock, J.M., 2012. In: Jan, P., de Ruiter, (Eds.), Formal Features of Questions, pp. 103-122.

Sadock, J.M., Zwicky, A.M., 1985. Speech act distinctions in syntax. In: Shopen, T. (Ed.), Language Typology and Syntactic Description, Volume I: Clause Structure. Cambridge University Press, Cambridge, pp. 155-196.

San Roque, L., 2008. An Introduction to Duna Grammar (PhD dissertation). Australian National University.

San Roque, L., Loughnane, R., 2012. The New Guinea highlands evidentiality area. Linguist. Typol. 16, 111-167.

Schlenker, P., 2003. A plea for monsters. Linguist. Philos. 26, 29-120.

Schlichter, A., 1986. The origins and deictic nature of Wintu evidentials. In: Chafe, W.L., Nichols, J. (Eds.), Evidentiality: The Linguistic Encoding of Epistemology. Ablex, Norwood, NJ, pp. 46-59.

Searle, J., 1969. Speech Acts: An Essay in the Philosophy of Language. Cambridge University Press, Cambridge.

Seyoum, M., 2008. A Grammar of Dime. LOT, Utrecht.

Speas, M., 2004. Evidentiality, logophoricity and the syntactic representation of pragmatic features. Lingua 114, $255-276$.

Speas, M., Tenny, C., 2003. Configurational properties of point of view roles. In: Di Sciullo, A.M. (Ed.), Asymmetry in Grammar. John Benjamins, Amsterdam, pp. 315-344.

Stivers, T., Rossano, F., 2010. Mobilizing response. Res. Lang. Soc. Interact. 43, 3-31.

Stivers, T., Rossano, F., 2012. Mobilizing response in interaction: a compositional view of questions. In: De Ruiter, J.P. (Ed.), Questions: Formal, Functional and Interactional Perspectives. Cambridge University Press, Cambridge, pp. 58-80.

Stivers, T., Enfield, N.J., Levinson, S.C., 2010. Question-response sequences in conversation across ten languages. J. Pragmat. 42 (10), 26152860 (Special Issue).

Tenny, C.L., 2006. Evidentiality, experiences, and the syntax of sentience in Japanese. J. East Asian Linguist. 15, 245-288.

Thurgood, G., 1986. The nature and origins of Akha evidential systems. In: Chafe, W.L., Nichols, J. (Eds.), Evidentiality: The Linguistic Encoding of Epistemology. Ablex, Norwood, NJ, pp. 214-222.

Tournadre, N., 1996. L'ergativite en Tibetain. Approche morphosyntaxique de la langue parlee. Peeters, Paris/Leuven.

Tournadre, N., 2008. Arguments against the concept of 'conjunct'/'disjunct' in Tibetan. In: Huber, B., Volkart, M., Widmer, P. (Eds.), Chomolangma Demawend und Kasbek. Festschrift für Roland Bielmeier zu seinem 65 Geburtstag. International Institute for Tibetan and Buddhist Studies, Halle, pp. 281-308.

Valenzuela, P.M., 2003. Evidentiality in Shipibo-Konibo, with a comparative overview of the category in Panoan. In: Aikhenvald, A.Y., Dixon, R.M. W. (Eds.), Studies in Evidentiality. John Benjamins, Amsterdam/Philadelphia, pp. 33-61.

Waldie, R., 2012. Evidentiality in Nuu-chah-nulth (PhD dissertation). The University of British Columbia.

Wechsler, S., in press. Self-ascription in conjunct/disjunct systems. In: Floyd, S., Norcliffe, E., San Roque, L. (Eds.), Egophoricity. John Benjamins, Amsterdam.

Willet, T.L., 1988. A cross-linguistic survey of the grammaticalization of evidentiality. Stud. Lang. 12, 51-97. 